\title{
Article
}

\section{Diversity of Silica-Scaled Chrysophytes in Central Vietnam}

\author{
Evgeniy Gusev *(D) and Nikita Martynenko
}

\author{
K.A. Timiryazev Institute of Plant Physiology RAS, IPP RAS, 35 Botanicheskaya St., 127276 Moscow, Russia \\ nikita-martynenko@yandex.ru \\ * Correspondence: gusev@ifr.moscow
}

Citation: Gusev, E.; Martynenko, N. Diversity of Silica-Scaled Chrysophytes in Central Vietnam. Water 2022, 14, 65. https://doi.org/ $10.3390 /$ w14010065

Academic Editors: Kay Van Damme and Alexey A. Kotov

Received: 30 November 2021

Accepted: 24 December 2021

Published: 30 December 2021

Publisher's Note: MDPI stays neutral with regard to jurisdictional claims in published maps and institutional affiliations.

Copyright: (c) 2021 by the authors. Licensee MDPI, Basel, Switzerland. This article is an open access article distributed under the terms and conditions of the Creative Commons Attribution (CC BY) license (https:/ / creativecommons.org/licenses/by/ $4.0 /)$.

\begin{abstract}
This paper focuses on the flora of scale-bearing chrysophytes from eight provinces located in the central part of Vietnam. Khanh Hoa, Phu Yen, Binh Dinh, Thua Thien Hue, Quang Tri, and Quang Binh provinces are located in the coastal area of Vietnam. Lam Dong and Dak Lak provinces represent mountain territories with an elevation of 500-2000 metres above sea level. In total, 212 water bodies of different origins were studied. Samples were obtained from swamp areas, lakes, rivers, reservoirs, ponds, and small temporary water bodies. In total, 76 taxa were identified by electron microscopic observations of samples. A total of 54 taxa were found in the mountainous provinces, while 73 were found in the coastal provinces. Of these, 51 species are common for both areas. The most diverse was the genus Mallomonas with 66 species, varieties, and forms; followed by Synura with 7 taxa; Chrysosphaerella with 2; and Spiniferomonas with 1. Seven taxa of the genus Mallomonas were not identified to the lower rank. All these unidentified specimens may potentially represent new species for science. Ten taxa are reported for the first time in Vietnam.
\end{abstract}

Keywords: Central Vietnam; tropics; freshwaters; flora; silica-scaled chrysophytes; Mallomonas; Synura; Chrysosphaerella; Spiniferomonas

\section{Introduction}

Tropical Asia has a rich flora and fauna; however, compared with the Neotropics and Africa, it has been studied less, especially regarding the biodiversity of freshwater ecosystems [1]. Algae are often omitted from total biodiversity estimations due to their microscopic size, the time-consuming methods for identification, and insufficiently developed species concepts for many groups $[2,3]$. The rates of human population growth are among the highest in the tropics, which leads to rapid rates of land conversion of tropical landscapes and biodiversity loss [4]. Vietnam belongs to the Indo-Burma biodiversity hotspot, one of the 35 areas on Earth that have exceptionally high concentrations of endemic species and the greatest risk of them disappearing because of heavy human impact [5]. It is estimated that there are about 13,500 vascular plant species in the Indo-Burma hotspot, of which about $52 \%$ are endemic [6]. Unfortunately, the algal diversity of Indo-Burma is still poorly known [7].

The total area of inland waters of Vietnam is about $6 \%$ of the country's territory. For comparison, the relative size of the freshwater area of neighbouring Cambodia and Laos is two and a half times smaller, and that of Thailand is twelve times smaller [8]. It is not surprising that various freshwater and brackish water habitats play an important role for the biodiversity of Vietnam, the entire Indo-China Peninsula, and even more broadly, the Indo-Burma biogeographic region as a whole [9]. The climatic, geographical, and natural diversity of these habitats determines its unique richness and the significance of biodiversity that characterises this region of Southeast Asia. Recently, there has been a significant increase in interest in the study of protists in Vietnam [10-14]. In the last decade, many new and endemic taxa of algae and heterotrophic protists have been described from freshwaters of the country, including diatoms [15-21], cryptomonads [22,23], heterotrophic flagellates [24,25], centrohelid heliozoans [26], and testate amoebae [27]. 
Chrysophyte algae (class Chrysophyceae) represent an extensive but rather poorly studied group of algae with underestimated diversity, a complex evolutionary history, and many unresolved problems in their phylogeny [28-30]. The study of the diversity and taxonomy of chrysophytes is complicated by the fact that they are hard-to-cultivate organisms, which hampers their molecular study. As a consequence, there are only a small number of cultures, and for most of the species described on the basis of morphological characteristics, cultures and sequence data are absent. However, among this large group, there are species with siliceous covers (scales, spines, and bristles), which have a complex ultrastructure and provide reliable characteristics for morphological species differentiation [29]. Moreover, the developed system of morphological criteria for distinguishing taxa (morphological species concept) is considered one of the best among the protists and, in general, has been confirmed with molecular data [29,31-35]. Hence, the majority of the known species of silica-scaled chrysophytes can be identified correctly. It also allows researchers to use previously accumulated information for generalisations and comparison with modern data. Morphological studies are based on the use of transmission or scanning electron microscopy (TEM or SEM, respectively) to reveal the ultrastructure of siliceous elements of cell covers [29]. Electron microscopic studies of silica-scaled chrysophytes began in the 1950s [36-40]. Since then, confirmation of their findings by electron micrographs has become mandatory, making this a group of model protists for studying biogeographic issues [41-44]. Silica-scaled chrysophytes are used widely in water monitoring and palaeoecological studies as indicator species $[45,46]$.

The distribution of silica-scaled chrysophytes has been studied unevenly. Most of the studies have been carried out in the temperate zone, from which most species have been described [47]. An extensive database of diversity and the distribution of silica-scaled chrysophytes has been developed for Europe [48]. The data on the diversity, distribution, and ecology of this group in North America have been presented in numerous works, [49-53], etc.

At the same time, the tropical region is still poorly studied [47]. For a long time, scalebearing chrysophytes have been thought to be restricted to temperate waters; however, studies of the region using electron microscopy, which began in the late 1970s, revealed an interesting flora $[44,54]$. Data on the diversity and distribution of silica-scaled chrysophytes from the tropical region is highly fragmented. Several regions have been explored in tropical Asia. One of the first studies of the tropics was conducted in Bangladesh in the 1970s [55]. Extensive research has been carried out in India [56,57]. Sporadic studies have been carried out in Malaysia, Sri Lanka, and Papua New Guinea [41,58-60]. Studies of tropical Australia have revealed many interesting taxa [58,61-64]. Indonesia has also attracted the attention of researchers on several occasions [41,65-67]. Several works are devoted to the study of the tropics and subtropics of China [68,69]. The result of these studies has been the identification of a fairly rich flora of the tropical region and the description of several species new to science, many of which are still considered endemic to the tropical region and, most often, are found in a limited area. However, it is still too early to speak about the completeness of the study of this region. Silica-scaled chrysophytes in Vietnam have also been studied unevenly. The first paper based on SEM of silica-scaled chrysophytes included the results of investigations of eight reservoirs and was published in 2011 [70]. Subsequently, the main research attention has been focused on special habitats, such as swamps in Cam Ranh Peninsula [71,72], wetlands of Cat Tien National Park [73], the Mekong Delta [74], and a reservoir in mountains [75]. Information about diversity of algae from the order Synurales in the Northern Vietnam has also been published recently, including the description of two new species [76-78]. In addition, a number of new species for science have been described from individual regions of the country [71,76-91]. However, Central Vietnam, except for certain areas of the Khanh Hoa province, has not yet been studied. In this work, we fill this gap. We studied the diversity of silica-scaled chrysophytes in both mountainous and lowland territories of Central Vietnam, covering eight provinces 
and 212 localities of different origins, to identify the most characteristic species for the studied area and to describe the distribution of rare and endemic species of the region.

\section{Materials and Methods}

Water samples from 212 localities in 8 provinces of Vietnam are included in this study (Figure 1, Table S1). Khanh Hoa, Phu Yen, Binh Dinh, Thua Thien Hue, Quang Tri, and Quang Binh provinces are located in the coastal area of Vietnam. Lam Dong and Dak Lak provinces represent mountain territories with an elevation of 500-2000 m above sea level. Samples were taken during an expedition of the Russian-Vietnamese Tropical Centre (Ecolan 3.2 project) in 2010-2019. The studied area has a monsoon tropical climate. More detailed data about climate characteristics are presented by Schmidt-Thomé et al. [92] and Pavlov and Zvorykin [10].

Samples were collected from the surface water layer by using a plankton net (mesh size $=20 \mu \mathrm{m})$. When using a mesh with such size, some small species can be overlooked in the study. However, our experience shows that organisms larger than $7 \mu \mathrm{m}$ are present in samples. After sampling, the material was prepared for further investigation. For electron microscopy, an aliquot of each sample was washed by repeated centrifugation in deionised water. Drops of the washed sample were dried or digested for 4-5 min in sulfuric acid with potassium dichromate. For SEM, samples were placed on aluminium stubs and coated with gold for $10 \mathrm{~min}$. Observations were carried out with a JEOL 6510 LV scanning electron microscope. For TEM, formvar-coated grids (EMS FF200-Cu-50, Electron Microscopy Sciences) were used, and observations were made on a JEM-1011 transmission electron microscope. Specific conductance, $\mathrm{pH}$, and temperature measurements were measured with a Hanna HI 9828 device (Hanna Instruments, Inc., Smithfield, RI, USA). The chlorophyll $a$ concentrations were determined using a previously described methodology $[93,94]$. Water was concentrated on membrane filters with a pore diameter of $1.2 \mu \mathrm{m}$ and then placed in a container with $90 \%$ ethanol. The chlorophyll extraction was carried out for at least $24 \mathrm{~h}$. Spectrophotometric analysis of the extracts for their optical density at three wavelengths in the red spectral region was performed and optical density reading at $750 \mathrm{~nm}$ was subtracted from these readings to correct for "background" interferences. To calculate the concentration of chlorophyll $a$, we used the formula given in [94]. The classification of Nurnberg and Shaw [95] was used to assess the trophic state based on the concentration of chlorophyll $a$ in water. The taxonomic identification was based on many works cited and discussed later in this article.

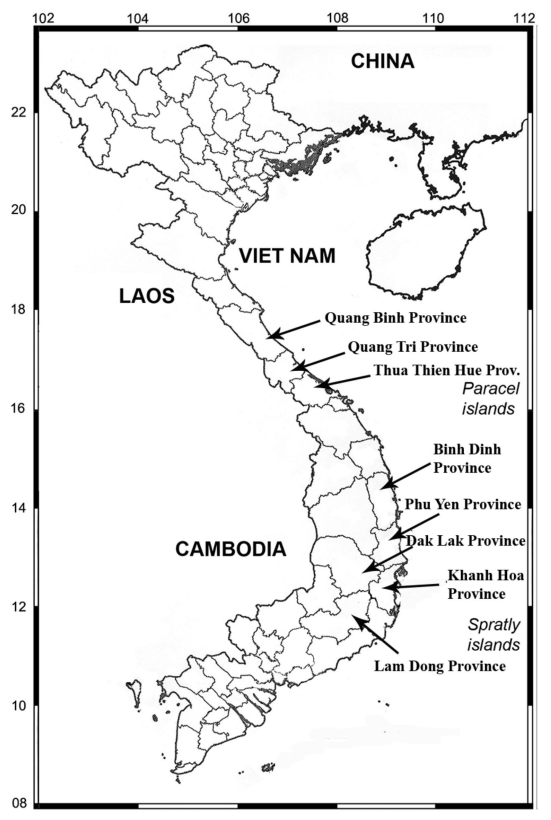

Figure 1. Geographical position of the studied area. 


\section{Results}

A total of 76 taxa were identified at the 212 localities in Central Vietnam (Tables 1 and S3-S10 and Figures 2-5). Sixty-six taxa belonged to the genus Mallomonas, seven taxa belonged to the genus Synura, two taxa were from the genus Chrysosphaerella, and one was from Spiniferomonas. We excluded from the analysis numerous morphotypes of the heterotrophic genus Paraphysomonas. Seven taxa of the genus Mallomonas were not identified to the lower rank. All these taxa are potentially new species for science.

Table 1. List of silica-scaled chrysophytes found in eight provinces of Central Vietnam. New taxa for Vietnam are given in bold, "+" indicates the presence of taxon.

\begin{tabular}{|c|c|c|c|c|c|c|c|c|}
\hline \multirow[b]{2}{*}{ Taxon } & \multicolumn{8}{|c|}{ Provinces } \\
\hline & $\begin{array}{l}\text { Lam } \\
\text { Dong }\end{array}$ & $\begin{array}{l}\text { Dak } \\
\text { Lak }\end{array}$ & $\begin{array}{l}\text { Khanh } \\
\text { Hoa }\end{array}$ & $\begin{array}{l}\text { Phu } \\
\text { Yen }\end{array}$ & $\begin{array}{l}\text { Binh } \\
\text { Dinh }\end{array}$ & $\begin{array}{c}\text { Thua } \\
\text { Thien Hue }\end{array}$ & $\begin{array}{l}\text { Quang } \\
\text { Tri }\end{array}$ & $\begin{array}{l}\text { Quang } \\
\text { Binh }\end{array}$ \\
\hline Mallomonas acaroides Perty emend. Iwanoff & + & & & & & & & \\
\hline M. akrokomos Ruttner & + & & & + & & + & & \\
\hline M. adamas Harris \& Bradley & + & & + & + & + & + & & \\
\hline $\begin{array}{l}\text { M. bangladeshica (E. Takahashi \& T. Hayakawa) } \\
\text { Siver \& A.P. Wolfe }\end{array}$ & & + & + & + & & + & & \\
\hline M. binocularis Siver & & & + & & & + & & \\
\hline M. bronchartiana Compère & & + & + & + & + & & + & \\
\hline M. cattiensis Gusev, Doan-Nhu \& Nguyen-Ngoc & & + & + & + & + & + & & \\
\hline M. caudata Iwanoff & + & + & + & + & + & + & + & + \\
\hline M. ceylanica Dürrschmidt \& Cronberg & & + & + & & + & + & + & + \\
\hline M. crassisquama (Asmund) Fott & + & + & + & + & + & + & + & + \\
\hline M. crassisquama var. papillosa Siver \& Skogstad & + & & & & & & & + \\
\hline M. cf. cristata Dürrschmidt & & + & & + & & + & & + \\
\hline $\begin{array}{l}\text { M. distinguenda Gusev, Doan-Nhu, Nguyen-Ngoc } \\
\text { \& Kapustin }\end{array}$ & & & & & & + & & \\
\hline M. elevata Han Soon Kim & + & & + & + & + & + & & \\
\hline M. elongata Reverdin & & & & + & & & & + \\
\hline M. favosa f. favosa K.H. Nicholls & + & + & + & + & + & + & & \\
\hline M. favosa f. gemina Dürrschmidt \& Croome & & + & + & + & + & + & + & \\
\hline M. fimbriata Gusev & & & + & & & & & \\
\hline $\begin{array}{l}\text { M. furtiva Gusev, Certnerová, Škaloudová \& } \\
\text { Škaloud }\end{array}$ & + & & + & + & + & + & & \\
\hline M. harrisiae E. Takahashi & & & & & & + & & \\
\hline M. hexareticulata Jo, Shin, Kim, Siver \& Andersen & & + & + & & + & + & & + \\
\hline M. grata E. Takahashi & + & + & + & & + & & & \\
\hline M. guttata var. guttata Wujek & + & + & + & + & + & + & + & + \\
\hline M. guttata var. simplex Nicholls & + & + & + & + & + & + & + & \\
\hline M. kenyana (Wujek \& Asmund) Kapustin \& Gusev & + & + & + & + & + & + & + & + \\
\hline M. korshikovii Gusev & & & + & + & + & & & \\
\hline $\begin{array}{l}\text { M. lamii Gusev, Kulizin, Guseva, Shkurina \& } \\
\text { Kulikovskiy }\end{array}$ & & + & + & + & + & + & + & \\
\hline M. loricata Gusev, Shkurina \& Kulikovskiy & & + & + & + & + & + & + & \\
\hline M. lusca Gusev \& Kezlya & & & + & & & & & \\
\hline $\begin{array}{l}\text { M. mangofera Harris \& Bradley var. mangofera apud } \\
\text { Dürrschmidt (1983) }\end{array}$ & + & + & + & & + & & & \\
\hline $\begin{array}{l}\text { M. mangofera var. foveata (Dürrschmidt) } \\
\text { Kristiansen }\end{array}$ & + & + & + & + & + & + & + & \\
\hline $\begin{array}{l}\text { M. cf. mangofera var. reticulata (Cronberg) } \\
\text { Kristiansen }\end{array}$ & & + & + & + & + & + & + & \\
\hline M. mangofera var. sulcata Dürrschmidt & & & & + & + & + & + & \\
\hline $\begin{array}{l}\text { M. mangofera var. gracilis (Dürrschmidt) } \\
\text { Kristiansen }\end{array}$ & & & & & & + & & \\
\hline
\end{tabular}


Table 1. Cont.

\begin{tabular}{|c|c|c|c|c|c|c|c|c|}
\hline \multirow[b]{2}{*}{ Taxon } & \multicolumn{8}{|c|}{ Provinces } \\
\hline & $\begin{array}{l}\text { Lam } \\
\text { Dong }\end{array}$ & $\begin{array}{l}\text { Dak } \\
\text { Lak }\end{array}$ & $\begin{array}{l}\text { Khanh } \\
\text { Hoa }\end{array}$ & $\begin{array}{l}\text { Phu } \\
\text { Yen }\end{array}$ & $\begin{array}{l}\text { Binh } \\
\text { Dinh }\end{array}$ & $\begin{array}{c}\text { Thua } \\
\text { Thien Hue }\end{array}$ & $\begin{array}{l}\text { Quang } \\
\text { Tri }\end{array}$ & $\begin{array}{l}\text { Quang } \\
\text { Binh }\end{array}$ \\
\hline $\begin{array}{l}\text { M. minuscula Gusev, Guseva, Kezlya \& } \\
\text { Kulikovskiy }\end{array}$ & + & & + & + & + & + & & \\
\hline M. morrisonensis Croome \& P.A. Tyler & + & + & + & + & + & + & + & \\
\hline M. multisetigera Dürrschmidt & & & + & & + & + & & \\
\hline M. neoampla Gusev \& Siver & & & + & & & + & & \\
\hline M. ocellata Dürrschmidt \& Croome & + & + & + & + & + & + & & + \\
\hline Mallomonas cf. ouradion Harris \& Bradley & & & & + & & + & & \\
\hline M. papillosa Harris \& Bradley & & & & & & + & & \\
\hline M. paragrandis Gusev & & + & + & + & + & + & + & \\
\hline M. peronoides (K. Harris) Momeu \& Péterfi & & + & + & + & + & + & + & \\
\hline M. plumosa Croome \& Tyler & + & + & + & + & & + & + & \\
\hline M. portae-ferreae Péterfi \& Asmund & & + & + & & + & & & \\
\hline M. pseudobronchartiana Gusev, Siver \& Shin & & + & & & & & & \\
\hline $\begin{array}{l}\text { M. pseudomatvienkoae Jo, Shin, Kim, Siver \& } \\
\text { Andersen }\end{array}$ & + & + & + & + & + & + & + & \\
\hline M. pseudocratis Dürrschmidt & & & & & & & & + \\
\hline M. punctifera Korshikov & + & & & & & & & \\
\hline M. punctostriata Gusev \& Kulikovskiy & & & + & & & & & \\
\hline M. rasilis Dürrschmidt & + & + & + & + & + & + & & \\
\hline M. siderea Gusev \& Kulikovskiy & & & & + & + & + & + & + \\
\hline $\begin{array}{l}\text { M. cf. skvortsovii Gusev, Doan-Nhu, Nguyen-Ngoc } \\
\text { \& Kapustin }\end{array}$ & & & & + & & + & & \\
\hline $\begin{array}{l}\text { M. sorohexareticulata Jo, Shin, Kim, Siver \& } \\
\text { Andersen }\end{array}$ & + & + & + & & + & + & + & + \\
\hline M. spinosa Gusev emend. Wei \& Kristiansen & & + & + & + & + & + & + & \\
\hline M. splendens (G.S. West) Playfair & + & & + & + & & + & + & \\
\hline M. striata var. serrata Harris \& Bradley & + & & & & & + & & \\
\hline M. tonsurata Teiling & + & + & + & + & + & + & + & + \\
\hline M. tropica Dürrschmidt \& Croome & & & + & & + & + & & \\
\hline Mallomonas sp. 1 & + & + & + & + & + & & + & + \\
\hline Mallomonas sp. 2 & + & + & + & + & + & & + & + \\
\hline Mallomonas sp. 3 & & & + & & & & & \\
\hline Mallomonas sp. 4 & & & & + & + & + & + & \\
\hline Mallomonas sp. 5 & & + & & + & + & + & + & \\
\hline Mallomonas sp. 6 & & & + & & & & & \\
\hline Mallomonas sp. 7 & & & & & & + & & \\
\hline Synura australiensis Playfair & + & + & + & & & + & & \\
\hline S. echinulata Korshikov & + & + & + & + & & + & & \\
\hline S. mammillosa E. Takahashi & + & & & + & + & + & & + \\
\hline S. papillosa Kapustin, Gusev \& Siver & & + & + & + & + & + & + & \\
\hline S. sphagnicola (Korshikov) Korshikov & + & & & & & + & + & \\
\hline Synura sp. 1 (S. longitubularis / S. curtispina group) & + & + & + & + & + & + & + & + \\
\hline Synura sp. 2 (S. petersenii sensu lato group) & + & & + & & & & & \\
\hline Spiniferomonas trioralis E. Takahashi & + & + & + & + & + & & & + \\
\hline Chrysosphaerella annulata Kristiansen \& Tong & & + & & + & & + & & \\
\hline Ch. nichollsii Kapustin \& Gusev & + & + & + & + & + & + & + & + \\
\hline Total & 36 & 41 & 53 & 47 & 45 & 56 & 31 & 20 \\
\hline
\end{tabular}

Ten taxa were reported for the first time in Vietnam: Mallomonas bangladeshica (Figure 2D), M. elongata (Figure 2P), M. harrisiae (Figure 3A), M. mangofera var. gracilis (Figure 3O), M. mangofera var. sulcata (Figure 3N), M. papillosa (Figure 4B), M. punctifera (Figure 4J), M. striata var. serrata (Figure 4R-S), Synura mammillosa (Figure 5L), and S. sphagnicola (Figure $5 \mathrm{~N}$ ). New species for the flora of Vietnam were found to be quite rare in the samples (Tables S3-S10). Synura sphagnicola was found in 11 localities of 3 provinces and S. mammillosa in 10 localities of 5 provinces. Mallomonas bangladeshica was found in 
7 localities of 4 provinces, $M$. mangofera var. sulcata was found in 6 localities of 3 provinces, $M$. harrisiae in 4 localities, and M. mangofera var. gracilis in 3 localities in only Thua Thien Hue province. Other Mallomonas taxa, new to the Vietnamese flora, were found only twice: $M$. elongata in Quang Binh and Phu Yen provinces, M. striata var. serrata in Lam Dong and Thua Thien Hue provinces, M. punctifera only in Lam Dong province, and Mallomonas papillosa only in Thua Thien Hue province.

Thua Thien Hue (56 taxa) and Khanh Hoa (53 taxa) provinces had the most taxa of silica-scaled chrysophytes, followed by Phu Yen (47 taxa), Binh Dinh (45 taxa), Dak Lak (41 taxa), Lam Dong (36 taxa), and Quang Tri (31 taxa) provinces. The number of taxa found in Quang Binh province is much smaller (only 20), but this is primarily due to the small number of studied reservoirs, which, moreover, had similar abiotic parameters. A total of 54 taxa were found in the mountainous provinces, while 73 were found in the coastal provinces. Of these, 51 species are common for both areas. The high number of common taxa between mountain and lowland territories is not surprising because the reservoirs in coastal areas of Central Vietnam are fed mostly by tributaries from the mountains. However, three species, Mallomonas pseudobronchartiana (Dak Lak Province), M. acaroides, and M. punctifera (Lam Dong Province), were found only in mountainous areas. Interestingly, that last two species, found $>1000 \mathrm{~m}$ above sea level, are common in temperate latitudes and rare in the tropics.
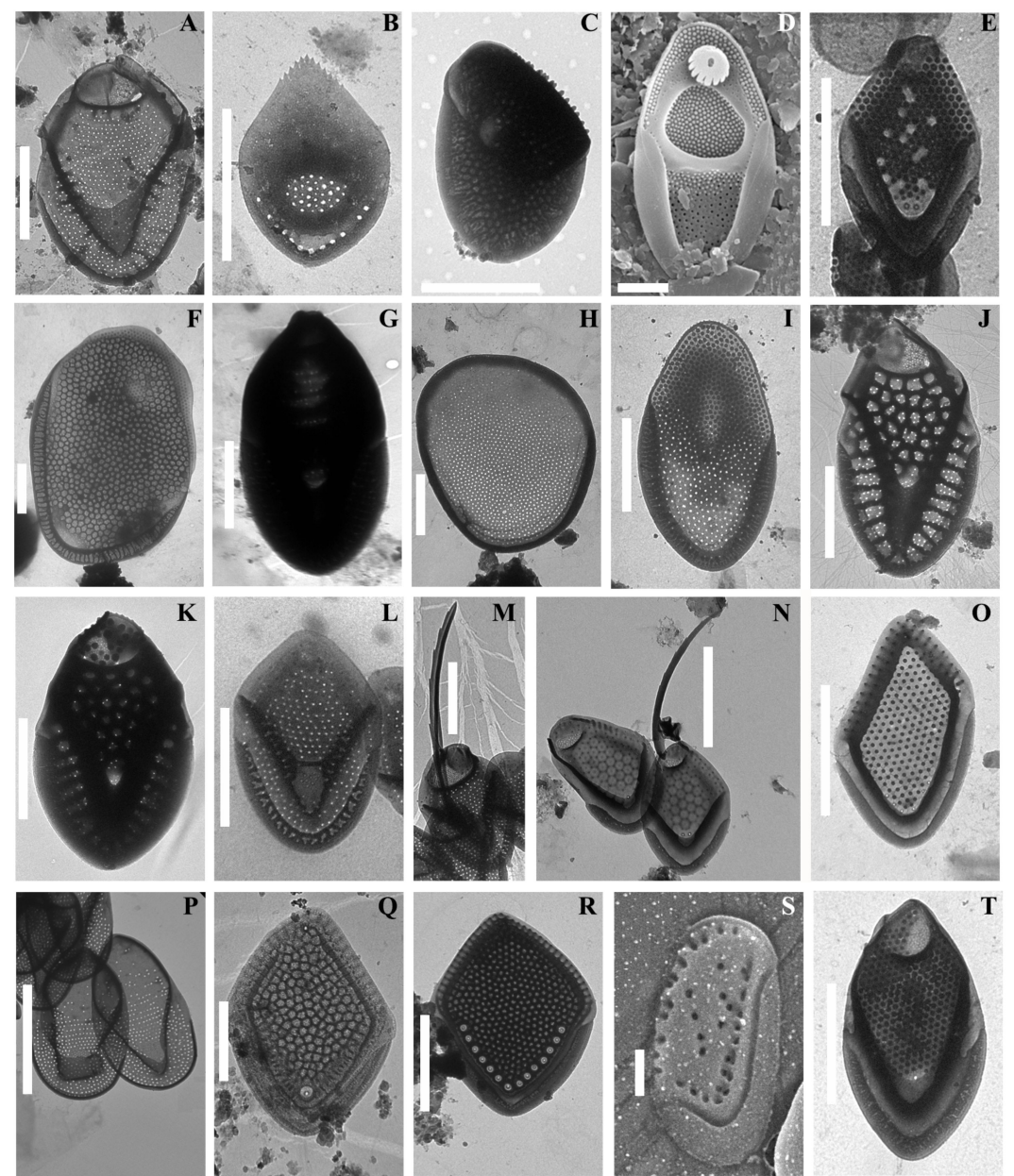

Figure 2. Scales and bristles of Mallomonas. (A) M. acaroides. (B) M. akrokomos. (C) M. adamas. (D) M. bangladeshica. (E) M. binocularis. (F) M. bronchartiana. (G) M. cattiensis. (H) M. caudata. (I) M. ceylanica. (J) M. crassisquama. (K) M. crassisquama var. papillosa. (L,M) M. cf. cristata. (N) M. distinguenda. (O) M. elevata. (P) M. elongata. (Q) M. favosa f. favosa. (R) M. favosa f. gemina. (S) M. fimbriata. (T) M. furtiva. Scale bars: (P): $5 \mu \mathrm{m}$; (A-C,E-N,R): $2 \mu \mathrm{m} ;(\mathbf{D}, \mathbf{O}, \mathbf{Q}, \mathbf{S}): 1 \mu \mathrm{m}$. TEM: (A-C,E-R,T); SEM: (D,S). 
Between 1 and 19 taxa were found per collection site (Tables S3-S10). The most chrysophytes taxa were found in swamp areas in Thua Thien Hue and Khanh Hoa provinces. Synura sp. 1 (S. curtispina/S. longitubularis morphotype) was the most frequently observed taxon (102 localities, frequency of occurrence is $48 \%$ ). Among frequently found taxa were also Mallomonas tonsurata (35\%), M. paragrandis (27\%), M. crassisquama and M. kenyana (25\% each), M. pseudomatvienkoae (23\%), M. guttata var. guttata (18\%), M. caudata (16\%), M. sp. 1 (15\%), M. morrisonensis (13\%), Chrysosphaerella nichollsii (13\%), Synura papillosa and M. favosa f. gemina (12\% each), and M. sorohexareticulata and M. loricata (10\% each).

The trophic state of water bodies, assessed on the basis of chlorophyll $a$ values, varied from oligotrophic to hypereutrophic (Tables S1 and S2). Most of the studied localities were eutrophic (76), followed by mesotrophic and hypereutrophic (50 and 47, respectively). Only 15 water bodies were oligotrophic. The number of species found in each type of water body was: 1-16 in eutrophic water bodies, 1-13 in oligotrophic water bodies, 1-14 in mesotrophic water bodies, and 1-18 in hypereutrophic water bodies. In total, 61 species were found in eutrophic water bodies, 64 in hypereutrophic water bodies, 44 in mesotrophic water bodies, and 30 in oligotrophic ones.
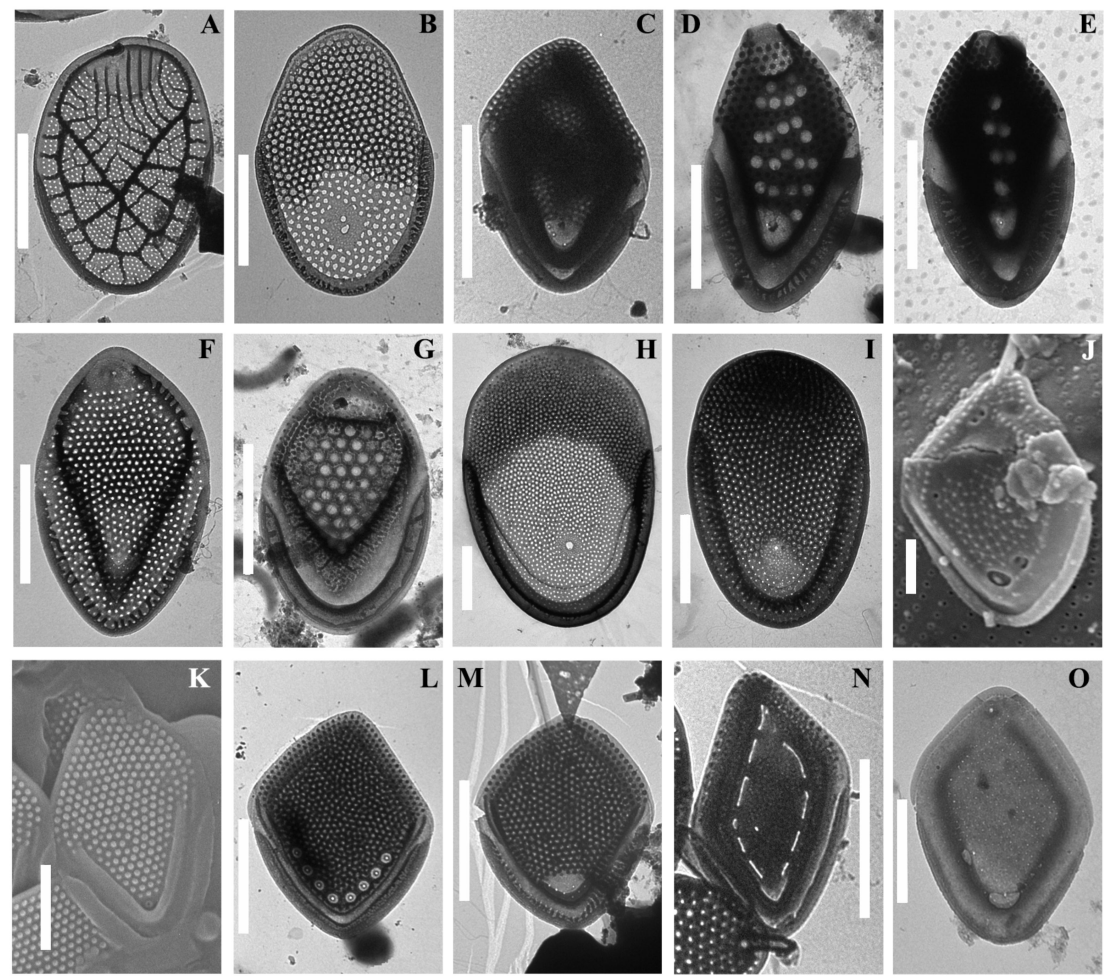

L M
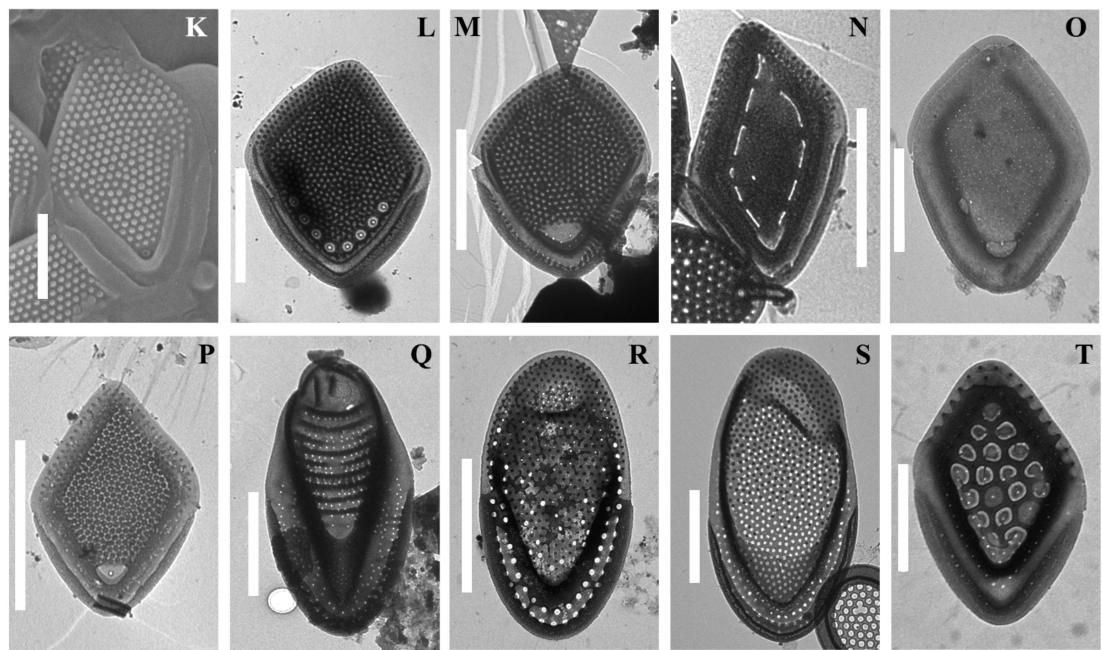

Figure 3. Scales of Mallomonas. (A) M. harrisiae. (B) M. hexareticulata. (C) M. grata. (D) M. guttata var. guttata. (E) M. guttata var. simplex. (F) M. kenyana. (G) M. korshikovii. (H) M. lamii. (I) M. loricata. (J) M. lusca. (K) M. mangofera var. mangofera. (L) M. mangofera var. foveata. (M) M. cf. mangofera var. reticulata. (N) M. mangofera var. sulcata. (O) M. mangofera var. gracilis. (P) M. minuscula. (Q) M. morrisonensis. (R) M. multisetigera. (S) M. neoampla. (T) M. ocellata. Scale bars: (P): $5 \mu \mathrm{m}$; (A-I,L-N,P,M-S): $2 \mu \mathrm{m}$; (K,O,T): $1 \mu \mathrm{m}$; (J): $0.5 \mu \mathrm{m}$. TEM: (A-I,L-T); SEM: (J,K). 
Several morphotypes were discovered that had not previously been described in the literature or had been cited as taxa of unclear systematic position. Some of these morphotypes were found singularly or were rare. Below, we provide a brief description of such scales, such that in the future, with the accumulation of sufficient data to describe these types of data, it would be possible to include our findings in the analysis.

Mallomonas sp. 1 (Figure 5B,C) belongs in the Mallomonas section. It has quite large oval tripartite scales, $6.6-7.6 \times 4.0-4.5 \mu \mathrm{m}$. A shield and flanges are lacking a secondary siliceous layer. The V-rib is large, acute and hooded, usually symmetrical, continuous with the arms of the anterior submarginal ribs. Numerous base-plate pores are placed irregularly or in regular transverse rows. A dome is large, rounded, or asymmetrical, with few ribs at the base. Such scale morphotypes were frequently found in Central Vietnam, in a total of 33 localities (15\% of all studied localities).
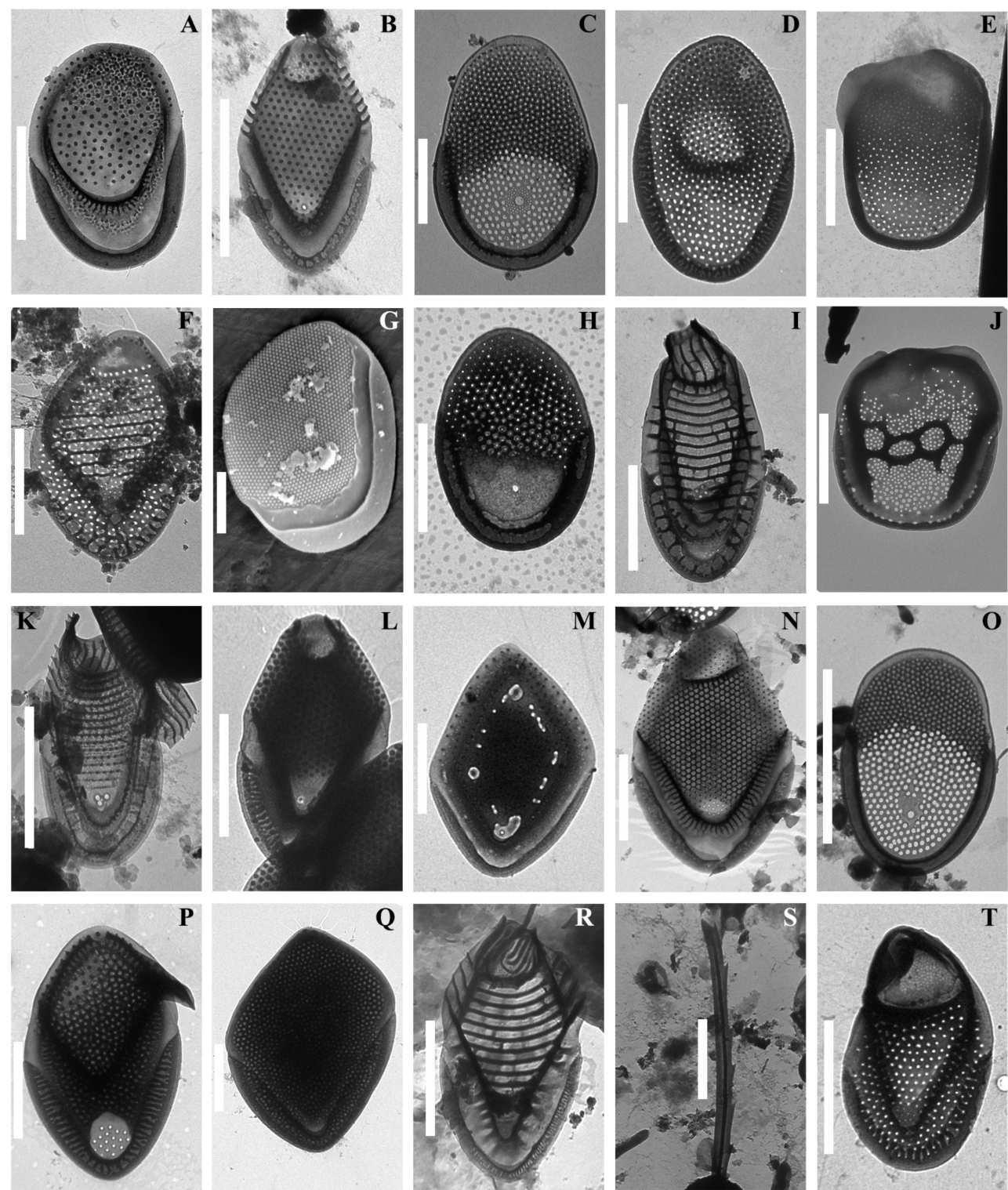

Figure 4. Scales and bristles of Mallomonas. (A) M. cf. ouradion. (B) M. papillosa. (C) M. paragrandis. (D) M. peronoides. (E) M. plumosa. (F) M. portae-ferreae. (G) M. pseudobronchartiana. (H) M. pseudomatvienkoae. (I) M. pseudocratis. (J) M. punctifera. (K) M. punctostriata. (L) M. rasilis. (M) M. siderea. (N) M. cf. skvortsovii. (O) M. sorohexareticulata. (P) M. spinosa. (Q) M. splendens. (R,S) M. striata var. serrata. (T) M. tonsurata. Scale bars: 0: $5 \mu \mathrm{m} ;(\mathbf{A}-\mathbf{L}, \mathbf{N}, \mathbf{P}-\mathbf{T}): 2 \mu \mathrm{m} ;(\mathbf{M}): 1 \mu \mathrm{m}$. TEM: (A-F,H-T); SEM: (G). 
Mallomonas sp. 2 (Figure 5D) also belongs in the Mallomonas section. Scales are oval, tripartite, $4.9-5.8 \times 3.3-4.0 \mu \mathrm{m}$. The dome is large, rounded, oval and asymmetrical. The V-rib is acute and slightly hooded, continuous with the arms of the anterior submarginal ribs. Anterior flanges are wide. The shield has a secondary siliceous layer forming circular or elongated oval meshes, unevenly distributed on the surface. Numerous base-plate pores are placed irregularly. The posterior rim is narrow, and the posterior flange is wide. Such scale morphotypes were found in Central Vietnam in 12 localities.

Mallomonas sp. 3 (Figure 5E) belongs in the Torquatae section. Body scales are rhombic, 3.4-4.5 $\times 2.1-3.1 \mu \mathrm{m}$. The shield is delimited by submarginal ribs (anterior and posterior) with arms of unequal length. The shield has a polygonal meshwork with papillae. Large pits are arranged along the arms of the posterior submarginal rib. Each pit contains a pore with the thickened surrounding ring. Pits are placed in chambers, formed by struts, perpendicular to the arms of posterior submarginal rib. Scales of Mallomonas sp. 3 were found only in one locality in Khanh Hoa Province.
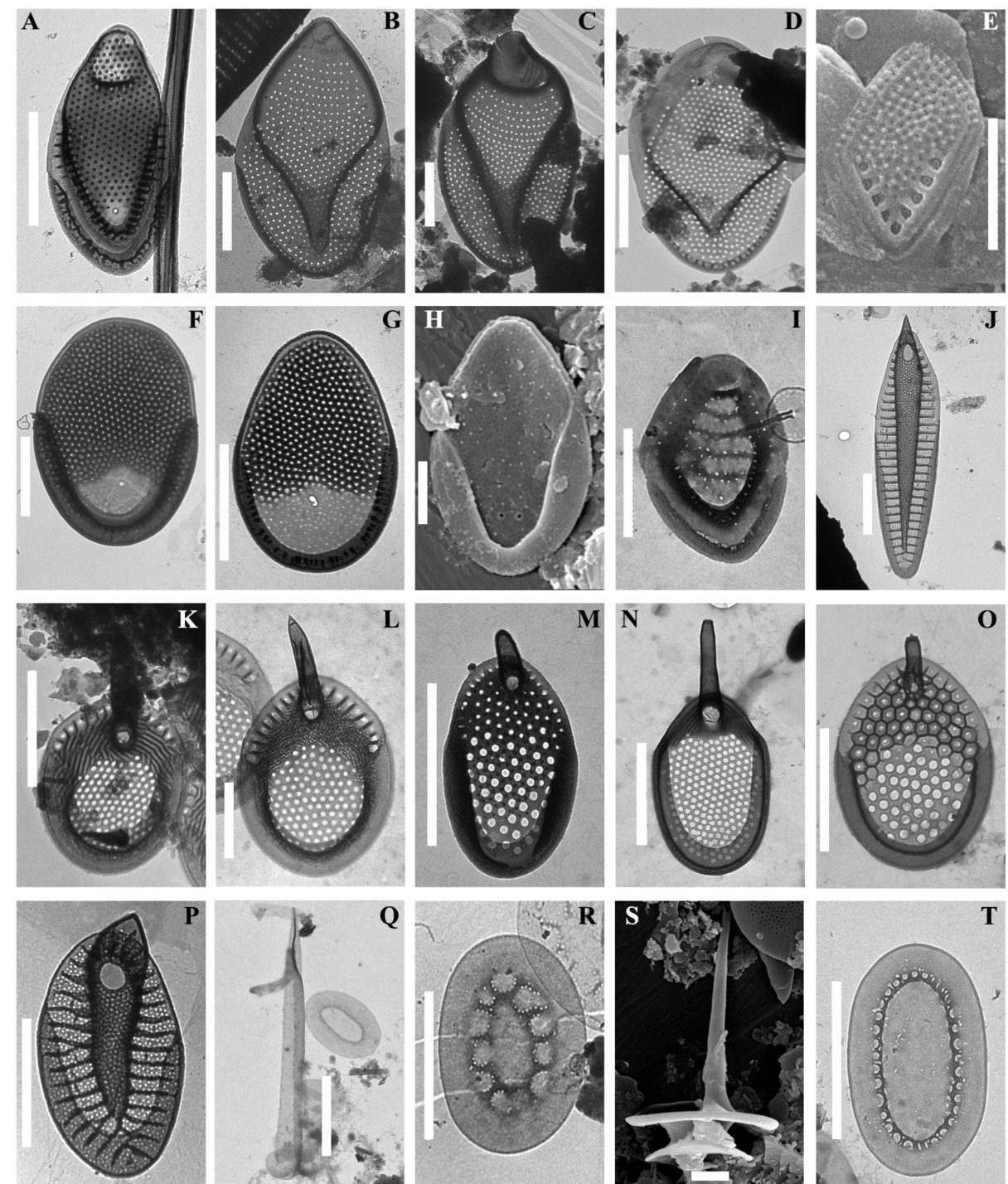

Figure 5. Scales of Mallomonas, Synura, Spiniferomonas and Chrysosphaerella. (A) Mallomonas tropica. (B,C) M. sp. 1. (D) M. sp. 2. (E) M. sp. 3. (F) M. sp. 4. (G) M. sp. 5. (H) M. sp. 6. (I) M. sp. 7. (J) Synura australiensis. (K) S. echinulata. (L) S. mammillosa. (M) Synura papillosa. (N) Synura sphagnicola. (O) S. sp. 1. (P) S. sp. 2. (Q) Spiniferomonas trioralis. (R) Chrysosphaerella annulata. (S,T) C. nichollsii. Scale bars: (A-G,J,K,M-R,T): $2 \mu \mathrm{m} ;(\mathbf{H}, \mathbf{I}, \mathbf{L}, \mathbf{S}): 1 \mu \mathrm{m}$. TEM: (A-D,F,G,I$\mathbf{R}, \mathbf{T})$; SEM: $(\mathbf{E}, \mathbf{H}, \mathbf{S})$. 
Mallomonas sp. 4 (Figure 5F) belongs in the Planae section. Scales are oval, 5.5-6.9 $\times 4.3-4.6 \mu \mathrm{m}$. A wide posterior rim encircles about half of the perimeter of the scale. A thick secondary meshwork covers more than the distal two thirds of the scale. Evenly spaced base-plate pores are restricted to the distal half of the scale and lacking in the proximal part without secondary reticulation where only a large pore is present at the centre. Mallomonas sp. 4 was found in Central Vietnam in 15 localities.

Mallomonas sp. 5 (Figure 5G) belongs in the Planae section. It has ovoid scales, $4.0-4.9 \times 2.4-3.0 \mu \mathrm{m}$. Numerous small base-plate pores are distributed evenly on the distal two thirds of the scale. A secondary reticulation with small rounded meshes covers the distal two thirds of the scales. A large proximal pore is in the posterior portion of the scale without secondary reticulation. This morphotype was found in Central Vietnam in 16 localities.

Mallomonas sp. 6 (Figure $5 \mathrm{H}$ ) belongs in the Planae section. The scale is oval, $4.0 \times 2.5 \mu \mathrm{m}$. A wide posterior rim encircles more than half of the scale perimeter. A secondary siliceous layer covers almost the entire surface of the scale, except a small area in the proximal part, adjacent to the posterior rim. There are two distinct rimmed pores in the proximal part of the scale. Only one scale was found in Khanh Hoa province.

Mallomonas sp. 7 (Figure 5I) belongs in the Marsupiales section. The scale is rounded rhombic, small, $2.0 \times 1.4 \mu \mathrm{m}$, with a small rounded dome. Posterior and anterior submarginal ribs are continuous, connected with four transverse ribs. There is a row of delicate papillae on both arms of the anterior submarginal rib and on the dome. Anterior flanges are wide and smooth. There is a base-plate with pores, proximally on the shield, and there is one distinct rimmed pore. The posterior rim is narrow and encircles about one third of the scale perimeter. Only one scale was found in Thua Thien Hue province.

\section{Discussion}

Expansion of agriculture, infrastructure development, and timber extraction are the major current threats to the biodiversity of Vietnam. Most of the territory of North Vietnam is under serious anthropogenic pressure. For example, most of Vietnam's rivers are currently regulated. There are about 4000 reservoirs, of which 460 are medium (1000-10,000 ha) or large ( $>10,000 \mathrm{ha})$ in size [96]. Modern reservoirs are often characterised by complex purposes and are used in hydropower programmes, for flood protection, navigation, irrigation, fishing, and other purposes. Most of the freshwater is used for irrigation in agriculture. The high population density of the country, rapidly developing industry, and agriculture lead to a significant anthropogenic load on the aquatic ecosystems of Vietnam. Currently, hydropower engineering and aquaculture are transforming these ecosystems at such an intensity that the nature of such transformations requires a special, well-balanced assessment [9]. In this situation, a thorough study of the processes occurring in freshwater ecosystems, the development of water quality criteria, and the principles of habitat protection for rare and important species of aquatic organisms are required. However, the first necessary step is to assess the existing diversity in the region.

Our investigations have revealed an exceptionally high diversity of silica-scaled chrysophytes, especially in the genus Mallomonas, for such a small area. This taxonomic diversity (76 taxa) exceeds values for all other studied tropical countries. For example, 58 species of scale-bearing chrysophytes were recorded in India [56,57], 49 taxa were recorded in tropical regions of China [68,69], and 40 species were recorded in Malaysia. In other tropical countries, the number of recorded taxa is $<30$.

Alongside the previous findings [72-75,97], there are now sixty-five Mallomonas taxa and seven Synura taxa that have been reported from Vietnam. With the representatives of Spiniferomonas, Chrysosphaerella, and Paraphysomonas, there have been 83 taxa of silica-scaled chrysophytes recorded in the country. Thirteen unidentified morphotypes of Mallomonas scales and two of Synura have also been reported in freshwaters of the country.

Mallomonas is the most diverse genus in the order Synurales and among all chrysophytes. It includes more than 200 species [47,98]. About one-third of the known species of 
the genus have now been found in Vietnam. Many Mallomonas species found in the country are known only from Vietnam or have a limited distribution in Southeast Asia. The most interesting finds in the studied region are discussed below.

Among eight taxa of Mallomonas that are new for the flora of Vietnam, four are widely distributed taxa, two can be considered endemic for Asia, and two are insufficiently studied taxa with a scattered distribution. All new taxa for the country from the genus Mallomonas were found only in a limited number of localities (from two to seven).

Mallomonas papillosa is a common taxon in temperate latitudes [47]. In warmer areas, it occurs rarely and has been reported from Malaysia [58], the tropics and subtropics of China [68,69], mountain areas of Papua New Guinea [60] and Indonesian Papua [99], India [57], Madagascar [100], Brazil [101], Ecuador [102], and the highlands of Colombia [54].

Mallomonas elongata, is a widely distributed species in temperate latitudes [47]. It has been reported in Vietnam from Khanh Hoa Province [70] (p. 196, Figures 5 and 6); however, this morphotype corresponds to Mallomonas sp. 1 in our study. Mallomonas elongata is characterised by the acute or rounded V-rib, which is hooded and continuous with the short anterior submarginal rib [103]. Scales and V-rib outlines are often asymmetrical. Some previous findings of M. elongata from Asia correspond to Mallomonas sp. 1 [58,68,69].

Mallomonas punctifera is a common species in northern temperate latitudes [47]. In the tropics, it has been reported only from Malaysia [58] and China [68,69].

Mallomonas striata var. serrata is considered a cosmopolitan taxon [47]. Most of the finds in the tropical region are from South America and Africa [100-102,104]. In Asia, this taxon has been reported from Malaysia [58], Papua New Guinea [60], and Indonesian Papua [99].

Mallomonas bangladeshica was initially described from Bangladesh [55]. It is a widely distributed species in the tropics and subtropics of Asia, namely Bangladesh [55], Sri Lanka [59], tropical and subtropical areas of China [68,69], Papua New Guinea [60], Indonesia [66], India [57], and South Korea [105].

Mallomonas harrisiae is a rare taxon that was first described from Japan [106] and was recently found in China [107]. It is reported here for the third time after its initial description.

Scales identified as Mallomonas mangofera var. gracilis were observed in three localities in Vietnam in Thua Thien province. Initially, M. mangofera var. gracilis was described from Chile [108]; subsequently, single finds were noted in Denmark [109], Finland [110], Malaysia [58], and China [69]. However, the diagnostic characters of this variety are rather dubious, and the illustrations in the original description are not clear enough. This variety differs from the type variety of $M$. mangofera by the shield with a weakly developed pattern of papillae, which are fused together to some extent, and with a pit-like depression with a pore at the base of the posterior submarginal rib. These characteristics can also be possessed by weakly silicified scales of other species of this complex. It is unclear whether scales identified as Mallomonas mangofera var. gracilis from such distant areas represent one species.

Mallomonas mangofera var. sulcata is the other rare and not fully described variety from the M. mangofera complex. After description in a Chilean water body [108], it has also been found in one locality in Singapore [41]. Mallomonas mangofera var. sulcata differs from other taxa of the M. mangofera complex by the presence of grooves (narrow long depressions) along the submarginal ribs. Despite the fact that only two long depressions are indicated in the diagnosis of the species, in the accompanying illustrations, there are more of them on some scales, and they can have different shapes [108] (p. 189, Figure 37). In Vietnam and Singapore, similar morphotypes have been found with numerous depressions, narrower than illustrated for organisms from the type habitat. Perhaps these are scales of a different taxon than the one described from Chile. Further research is needed to clarify this issue.

The use of molecular methods and approaches of geometric morphometry to study the diversity of silica-scaled chrysophytes has made it possible to re-evaluate morphological criteria to distinguish among species [32,35,111-114]. Studies of synuralean algae that combine morphological and molecular data clearly show that even slight differences in 
scale/bristle morphology are sufficient for species delimitation [115]. Such features as the location and size of pores on the basal plate, features of the reticulation of the secondary silica layer, the arrangement of papillae on the shield, the structure of bristles, and other features previously attributed to intraspecific variability can serve as reliable characteristics to distinguish among species. Consequently, it is necessary to take these conclusions into account when identifying taxa and to illustrate all "deviating" morphotypes. Therefore, we have carefully cited those morphotypes that do not correspond to the description of closely related species, we have provided their description, and we have pointed out differences from the descriptions in the diagnosis. The illustration of new morphotypes is an important step for further revision of the diversity and study of the biogeography of silica-scaled chrysophytes. Recently, several taxa have been described, which had been illustrated earlier as single scales of unidentified taxa. Examples include taxa such as Mallomonas spinosa [79], M. fimbriata [81], M. pseudobronchartiana [86], and M. lusca [116]. Analysis of images illustrated earlier under the epithets of other species ("deviating" morphotypes or misidentified taxa) from different regions of the world $[41,58,60,100]$ have helped clarify the distribution features of some recently described taxa, such as Mallomonas cattiensis [84], M. neoampla [82], M. furtiva [87], M. loricata [77], and M. siderea [78].

In this study, we found seven morphotypes of Mallomonas scales that could not be attributed to known taxa. However, it is not yet possible to describe them as new species. The first group consisted of well-distinguishable but rare morphotypes, represented by single scales. They require additional material for morphological description.

The scale of Mallomonas sp. 6 is similar to the body scales of M. ceylanica (Figure 2I). However, it is clearly distinguished by the long and wide posterior rim that encircles more than half of the scale perimeter and by the distinct rimmed pores in the proximal part of the scale. Scales of $M$. ceylanica have numerous simple pores in the proximal part, a narrower posterior rim, and an elliptical depression in the centre of the shield. The scale of Mallomonas sp. 6 represents a transitional type between the M. peronoides/M. ceylanica group and the M. matvienkoae group.

The scale of Mallomonas sp. 7 is similar to M. perpusilla Dürrschmidt and M. marsupialis Kristiansen \& Tyler, the only two species known in the Marsupiales section. Both species are rare and have restricted distribution. M. perpusilla was first described from New Zealand [117] and was found later in Australia [64]. M. marsupialis has only been described and known from Australia [64]. The found scales are similar to M. marsupialis in having transverse ribs. However, $M$. marsupialis has one stout and two weaker transverse ribs and narrow anterior flanges. M. perpusilla, unlike Mallomonas sp. 7, has three to four transverse ribs, connected by a few longitudinal ribs to form an open reticulum with few meshes. The anterior flanges of $M$. perpusilla have irregularly developed struts radiating from the anterior submarginal ribs. However, on some illustrations of specimens from the type habitats, there are images of scales with only transverse ribs and without longitudinal ones [117] (p. 95, Figures 14 and 15). It remains unclear whether the scale found in one habitat in Thua Thien Hue Province is a new species to science or a weakly silicified scale of a rare species, namely $M$. perpusilla.

Another group of unidentified taxa is represented by morphotypes that are part of complex groups of closely related species, such as Mallomonas elongata, M. corymbosa, $M$. matvienkoae, and M. favosa, and have morphological differences from the described taxa, but the species rank must be confirmed by molecular studies.

Mallomonas sp. 1 has a similar scale ultrastructure to the widely distributed M. elongata, also reported in our study. Both taxa lack a secondary siliceous layer on the shield and flanges and have a large V-rib and quite large scales. Mallomonas sp. 1, unlike M. elongata, has a symmetric outline of scales and a different V-rib shape, usually long arms of the anterior submarginal rib, and distinct rows of base-plate pores on the shield and flanges. More data on the bristle structure and molecular data of Mallomonas sp. 1 is needed to clarify its taxonomic status. A similar morphotype has also been reported in Malaysia [58] 
and Korea [118]. In Vietnam, this morphotype has also been reported from Northern Vietnam [97].

Mallomonas sp. 2 is similar to M. corymbosa Asmund \& Hilliard. Scales under the name $M$. corymbosa have often been documented from the tropical region $[55,68,69]$. However, $M$. corymbosa was first described from a northern area (Alaska) [119] and is now believed to have a bipolar distribution [47]. Scales of Mallomonas sp. 2 differ from scales of $M$. corymbosa (based on the original description) in size $(4.9-5.8 \times 3.3-4.0 \mu \mathrm{m}$ versus 5.8-7.2 $\times 3.4-5 \mu \mathrm{m})$, features of the development of the secondary silica layer on the shield, and wide anterior margins, especially on scales without a dome. Scales similar to ones of Mallomonas sp. 2 have been well illustrated in studies of silica-scaled chrysophytes in Bangladesh [55] and China [69]. In Vietnam, this morphotype has been reported in Northern Vietnam [97] and in the Mekong Delta under the name Mallomonas cf. corymbosa [74].

Scales of Mallomonas sp. 3 are similar to M. favosa f. favosa and M. favosa f. gemina. These taxa all have rhomboidal and slightly asymmetrical body scales. The shield of scales of these species has a reticulated meshwork. Well-developed anterior submarginal ribs on the scales of all three taxa have a number of transverse struts. These three taxa differ from each other in the form, structure, and position of pits, located near the posterior submarginal rib. Mallomonas sp. 3 differs from $M$. favosa $\mathrm{f}$. favosa by the presence of a distinct row of pits located on the shield along the posterior submarginal rib. Mallomonas favosa f. gemina also has such a row of pits. The differences between Mallomonas sp. 3 and M. favosa f. gemina include the size, shape, and number of pits. M. favosa f. gemina has numerous $(>10)$ small pits located on the shield along the arms of posterior submarginal rib. Pits $(<10)$ on the scales of Mallomonas sp. 3 represent quite large rectangular chambers, each containing a rimmed pore. Scales similar to Mallomonas sp. 3 have been reported from a single locality in Malaysia and one in Australia under the name Mallomonas favosa forma 2 [58].

Mallomonas sp. 4 and Mallomonas sp. 5 are representatives of the Planae section. Species without a V-rib, which are grouped in the Planae section, have a simpler scale structure and, accordingly, fewer potential diagnostic features to distinguish among species. However, molecular data have shown high diversity in this clade, resulting in the description of several new taxa in the Mallomonas matvienkoae and $M$. caudata species complexes [113]. For the delimitation of taxa, authors have used features such as the perforations on the scale's basal plate, the structure of the secondary silica layer, the ornamentation formed by papillae, and the structure of bristles. Molecular data have confirmed the importance of these structures to delimit taxa at the species level [113]. Our detailed studies of silica-scaled chrysophytes in Central Vietnam have revealed new morphotypes in the M. matvienkoae group. In general, the Mallomonas matvienkoae complex is a complicated group, which first needs typification of Mallomonas matvienkoae Asmund \& Kristiansen with molecular methods for its revision and further description of new species [77,113]. Mallomonas sp. 4 and Mallomonas sp. 5 are similar to M. pseudomatvienkoae (Figure 4H). Mallomonas sp. 4 differs from it by larger scales $(5.5-6.9 \times 4.3-4.6 \mu \mathrm{m}$ versus 3-5 $\times 2-3 \mu \mathrm{m}$ in M. pseudomatvienkoae), the shape of the reticulation of the secondary silica layer in the distal part of the scales, and the presence of papillae on the shield of the scales. Additional research is required to describe this organism. This morphotype is fairly common in Vietnam, where it has been reported from the Cat Tien National Park, swamp water bodies of the Cam Ranh Peninsula, Northern Vietnam, and the Mekong Delta [72-74,97]. Scales of Mallomonas sp. 5 are in size range of $M$. pseudomatvienkoae; however, they are clearly differentiated by the ovoid shape with a narrower distal part in contrast to the broadly oval and obovate scales of $M$. pseudomatvienkoae.

Some of the rare species we found, such as Mallomonas cf. cristata (Figure 2L,M), M. cf. ouradion (Figure 4A), and M. cf. skvortsovii (Figure 4N), we could not reliably identify, although morphologically they are similar to known taxa. With a high degree of probability, these are new species for science that are part of the complex of already described morphologically similar species. To clarify their status and description, additional 
molecular studies and/or additional material are required for a more thorough study of the scale ultrastructure. Mallomonas cristata was first described from Chile [120] and later found in many habitats throughout the world [47]. Specimens from Vietnam differ mainly by serrated bristles, while only 1-2 small teeth on distal portion of bristles originally were described for M. cristata. Mallomonas ouradion was described from the United Kingdom [121] and has a scattered distribution [47]. In contrast to the original description of M. ouradion, scales from Central Vietnam are wide-oval, with a wide posterior flange, with a V-rib shifted toward the centre of the scale, a weakly developed anterior rib, and well-developed anterior flanges. Mallomonas skvortsovii is a recently described species from Vietnam, known from only one locality in Cat Tien National Park [85]. In contrast to the original description of M. skvortsovii, scales from Central Vietnam do not have ribs on the dome and struts in the posterior rim, have numerous pores in the angle of the V-rib, and have raised anterior flanges.

We also observed a number of rare Mallomonas species. Mallomonas binocularis was found the third time in Vietnam. This rare taxon has been reported in a few localities in North America [122,123]. Mallomonas distinguenda was originally described in Cat Tien National Park, located in the Southern Vietnam [85], and found only for the second time after its description. Mallomonas korshikovii (Figure 3G) and M. neoampla (Figure 3S) are species, described from Khanh Hoa Province of Vietnam [71,82], and were also found in Thanh Hoa province in Northern Vietnam [97]. We have provided a few more localities where we observed these taxa. Mallomonas pseudobronchartiana (Figure 4G) was recently described from Vietnam and is also known from several localities in South Korea and the United States [86]. Here, we reported this taxon for second time in Vietnam. Mallomonas tropica (Figure 5A) is a rare taxon, previously reported only from the type locality in Malaysia [58] and one locality in Vietnam [71]. In our studies, it was reported from six more localities in two provinces.

Synura represents another species-rich genus of the order Synurales and includes more than 50 species [35]. We discovered two new species for the flora of Vietnam in our research.

Synura mammillosa is a widely distributed taxon [47]. In tropical Asia, this morphotype is known from China [68] and Indonesian Papua [99]. Synura sphagnicola is also a widely distributed taxon, which prefers humic acid waters [47]. In tropical Asia, it has been found in Malaysia [58] and China [68]. Scales of Synura sphagnicola from central provinces in Vietnam are characterised by the presence of several rows of ribs at the distal part.

By contrast, Synura sp. 1 (Figure 5O) is one of the most widespread species of synurophytes algae in Vietnam, as shown both in this study and earlier works $[72,73,97]$. It represents the S. curtispina/S. longitubularis morphotype. The identification of this taxon based on morphological data is problematic [35]. Both Synura curtispina (Petersen \& Hansen) Asmund and S. longitubularis Jo, Shin, Kim \& Siver, are almost indistinguishable from each other in terms of the morphological scale structure [114]. Our unpublished molecular data indicate that only S. longitubularis was found in water bodies of Vietnam. However, additional studies are needed regarding the distribution of this taxon.

Synura papillosa (Figure 5M) has recently been described from Vietnam [91]. Our research showed that it is widely distributed throughout Vietnam.

Among the two observed species of Chrysosphaerella, C. nichollsii (Figure 5S,T) was quite common, observed in 28 localities in Vietnam, and Chrysosphaerella annulata (Figure 5R) was found rarely-only in six sites. C. nichollsii has been described from Indonesia [66] and is now known only in Indonesia and Vietnam. However, based on the wide distribution of this species in Vietnam, it can be assumed that it is a common species for tropical Asia.

Chrysosphaerella annulata has been found in Vietnam, in Dong Nai province [124]. It is a widespread species in the tropical region $[54,55,57,59,68,69,100,125]$ and has been noted in the temperate zone [126].

Most of the species found in our study have restricted distribution patterns within regions with a warmer climate. The endemics of Vietnam and neighbouring countries are 
M. cattiensis, M. distinguenda, M. lusca, M. fimbriata, M. korshikovii, M. lamii, M. loricata, $M$. minuscula, M. neoampla, M. ocellata, M. paragrandis, M. punctostriata, M. siderea, M. spinosa, M. tropica, M. sp. 3, M. sp. 5, and Chrysosphaerella nichollsii.

The endemics of a wider area, including tropical and subtropical Asia, found in our studies include the following species: M. bangladeshica, M. elevata, M. favosa f. gemina, M. harrisiae, M. hexareticulata, M. ceylanica, M. grata, M. sorohexareticulata. M. sp. 1, and M. sp. 4.

Mallomonas bronchartiana, M. kenyana, M. morrisonensis, M. splendens, Synura australiensis, and S. papillosa are pantropic species and are sometimes found in the subtropics. Mallomonas plumosa is restricted in distribution to South Asia, Australia, and New Zealand [47].

Widely distributed taxa in our study are Mallomonas acaroides, M. akrokomos, M. adamas, M. caudata, M. crassisquama, M. elongata, M. favosa f. favosa, M. guttata var. guttata, $M$. multisetigera, M. papillosa, M. peronoides, M. portae-ferreae, M. pseudocratis, M. punctifera, $M$. rasilis, M. striata var. serrata, M. tonsurata, Synura echinulata, S. mammillosa, S. sphagnicola, and Spiniferomonas trioralis $[43,47]$. However, molecular studies are needed to confirm that these morphotypes are indeed widespread species and not cryptic taxa. Examples of cryptic/pseudo-cryptic species have been found-for example, in the M. furtiva/M. kalinae Rezácova [87] and S. curtispina/S. longitubularis [114] complexes.

These data confirm the inconsistency of the concept of cosmopolitan distribution of microorganisms [127-129] and are consistent with the data of a moderate endemic model, namely that some species have a cosmopolitan distribution and many others have limited habitats $[35,130,131]$. Our data show that the study and revision of the tropical flora of microalgae should lead to a revision of the widely discussed theory of cosmopolitan distribution of protists.

Supplementary Materials: The following supporting information can be downloaded at: https: / / www.mdpi.com/article/10.3390/w14010065/s1, Table S1. Basic characteristics of the localities $(\mathrm{pH}$, temperature, specific conductance, chlorophyll $a$ concentrations, elevation, and tropic state of analysed water bodies). Table S2. Distribution of the studied waterbodies in Central Vietnam by trophic categories based on the concentration of chlorophyll a in the surface layer. Tables S3-S10. Distribution of Mallomonas, Synura, Spiniferomonas, and Chrysosphaerella species in water bodies of eight studied provinces.

Author Contributions: E.G., sampling, writing and drafting of manuscript, T.E.M. and S.E.M. observations, identification. N.M., sample preparation, T.E.M. and S.E.M. observations, editing of manuscript. All authors have read and agreed to the published version of the manuscript.

Funding: Financial support was provided by the Russian Science Foundation (20-14-00211) for the TEM and SEM studies, sample processing, and identification. Analysis of environmental parameters was performed within the state assignment of the Ministry of Science and Higher Education of the Russian Federation (theme no. 121041200194-7).

Institutional Review Board Statement: Not applicable.

Informed Consent Statement: Not applicable.

Data Availability Statement: Not applicable.

Acknowledgments: The authors are grateful to staff of the Russian-Vietnam Tropical Centre (Hanoi and Nha Trang, Vietnam) for their assistance in sampling during the project "Ecolan 3.2." In addition, we are grateful to the staff of the Centre of Electron Microscopy of Papanin's Institute for Biology of Inland Waters, RAS, for technical assistance. The authors are grateful to anonymous reviewers for their remarks that improved the manuscript.

Conflicts of Interest: The authors declare no conflict of interest. 


\section{References}

1. Dudgeon, D. The Ecology of Tropical Asian Rivers and Streams in Relation to Biodiversity Conservation. Annu. Rev. Ecol. Syst. 2000, 31, 239-263. [CrossRef]

2. Santos, L.; Santos, F.; Gil, C.; Pereira, M. Diversity of Freshwater Algae. In Aquatic Ecology of the Mondego River Basin Global Importance of Local Experience; Graca, M.A., Pardal, M.A., Marques, J.C., Eds.; Imprensa da Universidade de Coimbra: Coimbra, Portugal, 2002; pp. 63-103.

3. Andersen, R.A. Diversity of Eukaryotic Algae. Biodivers. Conserv. 1992, 1, 267-292. [CrossRef]

4. Beaudrot, L.; Ahumada, J.A.; O’Brien, T.; Alvarez-Loayza, P.; Boekee, K.; Campos-Arceiz, A.; Eichberg, D.; Espinosa, S.; Fegraus, E.; Fletcher, C.; et al. Standardized Assessment Of Biodiversity Trends In Tropical Forest Protected Areas: The End Is Not in Sight. PLoS Biol. 2016, 14, e1002357. [CrossRef]

5. Mittermeier, R.A.; Turner, W.R.; Larsen, F.W.; Brooks, T.M.; Gascon, C. Global Biodiversity Conservation: The Critical Role of Hotspots. In Biodiversity Hotspots: Distribution and Protection of Conservation Priority Areas; Zachos, F.E., Habel, J.C., Eds.; Springer: Berlin/Heidelberg, Germany, 2011; pp. 3-22. [CrossRef]

6. Van Dijk, P.P.; Tordoff, A.W.; Fellowes, J.; Lau, M.; Ma, J.S. Indo-Burma. In Hotspots Revisited: Earth's Biologically Richest and Most Endangered Terrestrial Ecoregions; Mittermeier, R.A., Robles-Gil, P., Hoffmann, M., Pilgrim, J., Brooks, T., Mittermeier, C.G., Lamoreux, J., da Fonseca, G.A.B., Eds.; CEMEX, Monterrey Conservation International: Washington, DC, USA; Mexico City, Mexico, 2004; pp. 323-330, ISBN 968-639-77-79.

7. Vyverman, W. The Indo-Malaysian North-Australian Phycogeographical Region Revised. Hydrobiologia 1996, 336, 107-120 [CrossRef]

8. WEPA. Water Environment Partnership in Asia Under the Initiative of the Ministry of the Environment of Japan. 2013. Available online: http:/ / www.wepa-db.net/index.html (accessed on 18 November 2021).

9. Allen, D.J.; Smith, K.G.; Darwall, W.R.T. The Status and Distribution of Freshwater Biodiversity in Indo-Burma; IUCN: Cambridge, UK; Gland, Switzerland, 2012; p. 160. ISBN 978-2-8317-1424-0.

10. Pavlov, D.S.; Zvorykin, D.D. Inland Water Ecology of Vietnam; KMK Press: Moscow, Russia, 2014; p. 435. (In Russian) [CrossRef]

11. Zagumyonnyi, D.G.; Gusev, E.S.; Mylnikov, A.A.; Mylnikov, A.P. Novel Species of Centrohelid Heliozoans (Centroplasthelida) for Freshwaters of Central and Southern Vietnam. Inland Water Biol. 2020, 13, 358-371. [CrossRef]

12. Tran, Q.H. The First Data on Testate Amoebae in the Coco River in Quang Nam and Da Nang Provinces, Vietnam. Mosc. Univ. Biol. Sci. Bull. 2019, 74, 207-214. [CrossRef]

13. Tran, Q.H. First Data on Testate Amoeba Composition in Tropical Karst Wetlands of Northern Vietnam in Relation to Type of Biotope and Season: New Bioindication Potentialities. Inland Water Biol. 2020, 13, 251-261. [CrossRef]

14. Tran, Q.H.; Tran, V.T.H.; Tikhonenkov, D.V. Freshwater Testate Amoebae from Waterbodies of North Vietnam with the Finding of Indicator Species. Limnology 2021, 22, 151-160. [CrossRef]

15. Gusev, E.S.; Kulikovskiy, M.S. Centric Diatoms from Vietnam Reservoirs with Description of One New Urosolenia Species. Nova Hedwig. Beih. 2014, 143, 111-126. [CrossRef]

16. Glushchenko, A.M.; Kuznetsova, I.V.; Kociolek, J.P.; Kulikovskiy, M.S. Karthickia verestigmata gen. et sp. nov.-An Interesting Diatom with Frustular Morphology Similar to Several Different Cymbelloid Diatom Genera. Phycologia 2019, 58, 605-613. [CrossRef]

17. Glushchenko, A.M.; Kociolek, J.P.; Kuznetsova, I.V.; Kezlya, E.M.; Kulikovskiy, M.S. Prestauroneis genkalii-A New Diatom Species (Bacillariophyceae: Stauroneidaceae) from Southeast Asia. Phytotaxa 2019, 414, 156-164. [CrossRef]

18. Glushchenko, A.M.; Kociolek, J.P.; Kuznetsova, I.V.; Kezlya, E.M.; Kulikovskiy, M.S. Neidiomorpha gusevii-A New Diatom Species (Bacillariophyceae: Neidiaceae) from Southeast Asia. Phytotaxa 2019, 415, 279-285. [CrossRef]

19. Kezlya, E.; Glushchenko, A.; Maltsev, Y.; Gusev, E.; Genkal, S.; Kuznetsov, A.; Kociolek, J.P.; Kulikovskiy, M. Placoneis cattiensis sp nov.-A New Diatom (Bacillariophyceae: Cymbellales) Soil Species from Cát Tiên National Park (Vietnam). Phytotaxa 2020, 460, 237-248. [CrossRef]

20. Kezlya, E.; Glushchenko, A.; Maltsev, Y.; Gusev, E.; Genkal, S.; Kociolek, J.P.; Kulikovskiy, M. Three New Species from Diatom Genus Placoneis (Bacillariophyceae: Cymbellales) with Comments on Cryptic Diversity in Placoneis elginensis-Group. Water 2021, 13,3276 .

21. Kulikovskiy, M.; Maltsev, Y.; Glushchenko, A.; Kuznetsova, I.; Kapustin, D.; Gusev, E.; Lange-Bertalot, H.; Genkal, S.; Kociolek, J.P. Gogorevia, a New Monoraphid Diatom Genus for Achnanthes exigua and Allied Taxa (Achnanthidiaceae) Described on the Basis of an Integrated Molecular and Morphological Approach. J. Phycol. 2020, 56, 1601-1613. [CrossRef]

22. Martynenko, N.A.; Gusev, E.S.; Kapustin, D.A.; Guseva, E.E.; Kulikovskiy, M.S. Cryptomonas cattiensis sp. nov. (Cryptophyceae: Cryptomonadales), a New Species Described from Vietnam. Phytotaxa 2020, 454, 127-136. [CrossRef]

23. Gusev, E.; Podunay, Y.; Martynenko, N.; Shkurina, N.; Kulikovskiy, M. Taxonomic Studies of Cryptomonas lundii Clade (Cryptophyta: Cryptophyceae) with Description of a New Species from Vietnam. Fottea 2020, 20, 137-143. [CrossRef]

24. Bass, D.; Tikhonenkov, D.V.; Foster, R.; Dyal, P.; Janouškovec, J.; Keeling, P.J.; Gardner, M.; Neuhauser, S.; Hartikainen, H.; Mylnikov, A.P.; et al. Rhizarian 'Novel Clade 10' Revealed as Abundant and Diverse Planktonic and Terrestrial Flagellates, including Aquavolon n. gen. J. Eukaryot. Microbiol. 2018, 65, 828-842. [CrossRef]

25. Irwin, N.A.T.; Tikhonenkov, D.V.; Hehenberger, E.; Mylnikov, A.P.; Burki, F.; Keeling, P.J. Phylogenomics Supports the Monophyly of the Cercozoa. Mol. Phylogenet. Evol. 2019, 130, 416-423. [CrossRef] [PubMed] 
26. Prokina, K.I.; Radaykina, L.V.; Mylnikov, A.P. Centrohelid heliozoans (Centroplasthelida Febvre-Chevalier et Febvre 1984) from Vietnam. Zool. Zhurnal 2019, 98, 965-977. [CrossRef]

27. Tran, Q.H.; Mazei, A.Y. Testate Amoebae from South Vietnam Waterbodies with the Description of New Species Difflugia vietnamica sp. nov. Acta Protozool. 2018, 57, 215-230. [CrossRef]

28. Del Campo, J.; Massana, R. Emerging Diversity within Chrysophytes, Choanoflagellates and Bicosoecids Based on Molecular Surveys. Protist 2011, 162, 435-448. [CrossRef]

29. Škaloud, P.; Kristiansen, J.; Škaloudová, M. Developments in The Taxonomy of Silica-Scaled Chrysophytes-From Morphological and Ultrastructural to Molecular Approaches. Nord. J. Bot. 2013, 31, 385-402. [CrossRef]

30. Kristiansen, J.; Škaloud, P. Chrysophyta. In Handbook of the Protists, 2nd ed.; Archibald, J.M., Simpson, A.G.B., Slamovits, C.H., Eds.; Springer International Publishing: Cham, Switzerland, 2017; pp. 331-366. [CrossRef]

31. Škaloudová, M.; Škaloud, P. A New Species of Chrysosphaerella (Chrysophyceae: Chromulinales), Chrysosphaerella rotundata, sp nov., from Finland. Phytotaxa 2013, 130, 34-42. [CrossRef]

32. Scoble, J.M.; Cavalier-Smith, T. Scale Evolution in Paraphysomonadida (Chrysophyceae): Sequence Phylogeny and Revised Taxonomy of Paraphysomonas, New Genus Clathromonas, and 25 New Species. Eur. J. Protistol. 2014, 50, 551-592. [CrossRef] [PubMed]

33. Siver, P.A.; Jo, B.Y.; Kim, J.I.; Shin, W.; Lott, A.M.; Wolfe, A.P. Assessing the Evolutionary History of The Class Synurophyceae (Heterokonta) Using Molecular, Morphometric, and Paleobiological Approaches. Am. J. Bot. 2015, 102, 921-941. [CrossRef] [PubMed]

34. Čertnerová, D.; Čertner, M.; Škaloud, P. Molecular Phylogeny and Evolution of Phenotype in Silica-Scaled Chrysophyte Genus Mallomonas. J. Phycol. 2019, 55, 912-923. [CrossRef]

35. Škaloud, P.; Škaloudová, M.; Jadrná, I.; Bestová, H.; Pusztai, M.; Kapustin, D.; Siver, P.A. Comparing Morphological and Molecular Estimates of Species Diversity in the Freshwater Genus Synura (Stramenopiles): A Model for Understanding Diversity of Eukaryotic Microorganisms. J. Phycol. 2020, 56, 574-591. [CrossRef] [PubMed]

36. Manton, I. Observations with the Electron Microscope on Synura caroliniana Whitford. Proc. Leeds Phil. Soc. 1955, 6, 306-316.

37. Petersen, J.B.; Hansen, J.B. On the Scales of Some Synura Species; Biologiske Meddelelser udgivet af Det Kongelige Danske Videnskabernes Selskab: Copenhagen, Denmark, 1956; Volume 23, pp. 1-27.

38. Fott, B.; Ludvík, J. Die submikroskopische Struktur der Kieselschuppen bei Synura und ihre Bedeutung für die Taxonomie der Gattung. Preslia 1957, 29, 5-16.

39. Asmund, B. Electron Microscope Observations on Mallomonas caudata and Some Remarks on Its Occurrence in Four Danish Ponds. Bot. Tidsskr. 1955, 52, 163-168.

40. Fott, B. Scales of Mallomonas Observed in the Electron Microscope. Preslia 1955, 27, 280-282.

41. Neustupa, J.; Řezáčová, M. The genus Mallomonas (Mallomonadales, Synurophyceae) in Several Southeast Asian Urban Water Bodies-The Biogeographical Implications. Nova Hedwig. 2007, 84, 249-259. [CrossRef]

42. ̌ezáčová, M.; Neustupa, J. Distribution of the Genus Mallomonas (Synurophyceae)—Ubiquitous Dispersal in Microorganisms Evaluated. Protist 2007, 158, 29-37. [CrossRef] [PubMed]

43. Kristiansen, J. Cosmopolitan chrysophytes. Syst. Geog. Plants 2000, 70, 291-300. [CrossRef]

44. Kristiansen, J. Dispersal and Biogeography of Silica-Scaled Chrysophytes. Biodivers. Conserv. 2008, 17, 419-426. [CrossRef]

45. Siver, P.A. The distribution of chrysophytes along environmental gradients: Their use as biological indicators. In Chrysophyte Algae: Ecology, Phylogeny and Development; Sandgren, C., Smol, J., Kristiansen, J., Eds.; Cambridge University Press: Cambridge, UK, 1995; pp. 232-268. [CrossRef]

46. Smol, J.P. Applications of chrysophytes to problems in paleoecology. In Chrysophyte Algae: Ecology, Phylogeny and Development; Sandgren, C., Smol, J., Kristiansen, J., Eds.; Cambridge University Press: Cambridge, UK, 1995; pp. 303-330. [CrossRef]

47. Kristiansen, J.; Preisig, H.R. Chrysophyta and Haptophyta Algae, 2nd part: Synurophyceae. In Süsswasserflora Von Mitteleuropa (Freshwater Flora of Central Europe); Büdel, B., Gärtner, G., Krienitz, L., Preisig, H.R., Schagerl, M., Eds.; Spektrum Akademisher Verlag, Springer: Berlin/Heidelberg, Germany, 2007; pp. 1-252, ISBN 978-3-8274-1701-5.

48. Škaloud, P.; Škaloudová, M.; Pichrtová, M.; Němcová, Y.; Kreidlová, J.; Pusztai, M. www.chrysophytes.eu—A Database on Distribution and Ecology of Silica-Scaled Chrysophytes in Europe. Nova Hedwigia Beiheft. 2013, 142, 141-146.

49. Siver, P.A. The biology of Mallomonas: Morphology, taxonomy and ecology. In Developments in Hydrobiology; Dumont, H.J., Ed.; Springer: Dordrecht, The Netherlands, 1991; Volume 63, p. 230. [CrossRef]

50. Siver, P.A. Synurophyte Algae. In Freshwater Algae of North America: Ecology and Classification, 2nd ed.; Wehr, J.D., Sheath, R.G., Kociolek, J.P., Eds.; Academic Press: Boston, MA, USA, 2015; pp. 607-651.

51. Siver, P.A.; Lott, A.M. Biogeographic Patterns in Scaled Chrysophytes from the East Coast of North America. Freshw. Biol. 2012, 57, 451-466. [CrossRef]

52. Siver, P.A.; Lott, A.M. The Scaled Chrysophyte Flora in Freshwater Ponds and Lakes from Newfoundland, Canada, and Their Relationship to Environmental Variables. Cryptogam. Algol. 2017, 38, 325-347. [CrossRef]

53. Nicholls, K.H.; Wujek, D.E. Chrysophycean Algae. In Freshwater Algae of North America: Ecology and Classification, 2nd ed.; Wehr, J.D., Sheath, R.G., Kociolek, J.P., Eds.; Academic Press: Boston, MA, USA, 2015; pp. 471-500.

54. Cronberg, G. Scaled Chrysophytes from the Tropics. Nova Hedwig. Beih. 1989, 95, 191-232.

55. Takahashi, E.; Hayakawa, T. The Synuraceae (Chrysophyceae) in Bangladesh. Phykos 1979, 18, $129-147$. 
56. Saha, L.C.; Wujek, D.E. Scale-bearing Chrysophytes from Tropical Northeast India. Nord. J. Bot. 1990, 10, 343-355. [CrossRef]

57. Wujek, D.E.; Saha, L.C. Scale-Bearing Chrysophytes (Chrysophyceae and Synurophyceae) from India. II. Nova Hedwig. 1996, 112, 367-377.

58. Dürrschmidt, M.; Croome, R. Mallomonadaceae (Chrysophyceae) from Malaysia and Australia. Nord. J. Bot. 1985, 5, 285-298. [CrossRef]

59. Dürrschmidt, M.; Cronberg, G. Contribution to The Knowledge of Tropical Chrysophytes: Mallomonadaceae and Paraphysomonadaceae from Sri Lanka. Algol. Stud. 1989, 54, 15-37.

60. Vyverman, W.; Cronberg, G. Scale Bearing Chrysophytes from Papua New Guinea. Nord. J. Bot. 1993, 13, 111-120. [CrossRef]

61. Croome, R.L.; Tyler, P.A. Mallomonas morrisonensis (Chrysophyceae) a New Species from Australia. Br. Phycol. J. 1983, 18, 383-389. [CrossRef]

62. Croome, R.L.; Tyler, P.A. Mallomonas sabulosa (Chrysophyceae), a New Species from Australia. Br. Phycol. J. 1986, 21, 93-96. [CrossRef]

63. Croome, R.; Diirrschmidt, M.; Tyler, P.A. Light and Electron Microscopical Investigation of Mallomonas splendens (G.S. West) Playfair (Mallomonadaceae, Chrysophyceae). Nova Hedwig. 1985, 41, 463-470.

64. Croome, R.; Kristiansen, J.; Qler, P.A. A Description of Mallomonas marsupialis nov. sp. (Synurophyceae), a New Chrysophyte from Australia, with Comments on the Endemicity of Australian Freshwater Algae. Nord. J. Bot. 1998, 18, 633-639. [CrossRef]

65. Cronberg, G.; Hickel, B. Mallomonas fenestrata sp. nov. and M. perforata sp. nov. (Chrysophyceae, Mallomonadaceae) from Tropical Lakes. Nord. J. Bot. 1985, 5, 105-110. [CrossRef]

66. Kapustin, D.A.; Gusev, E.S. Silica-Scaled Chrysophytes from West Java (Indonesia) Including Description of a New Chrysosphaerella Species. Nova Hedwig. Beih. 2019, 148, 11-20. [CrossRef] [PubMed]

67. Kapustin, D.A.; Gusev, E.S.; Kulikovskiy, M.S. Mallomonas papuensis sp. nov. (Chrysophyceae, Synurales), a New Species from The High Mountain Bog Pool in Papua Province, Indonesia. Phytotaxa 2019, 402, 281-287. [CrossRef]

68. Wei, Y.X.; Yuan, X.P. Studies on Silica-Scaled Chrysophytes from the Tropics and Subtropics of China. Nova Hedwig. Beih. 2001, $122,169-187$.

69. Wei, Y.X.; Yuan, X.P.; Kristiansen, J. Silica-Scaled Chrysophytes from Hainan, Guangdong Provinces and Hong Kong Special Administrative Region, China. Nord. J. Bot. 2014, 32, 881-896. [CrossRef]

70. Gusev, E.S.; Nguyen, T.H.T. Silica-Scaled Chrysophytes (Chrysophyceae and Synurophyceae) from Vietnam (Khanh Hoa and Quang Nam provinces). Nova Hedwig. 2011, 93, 191-199. [CrossRef]

71. Gusev, E.S. Studies on Synurophycean Algae from Mangrove Wetlands (Vietnam). Nova Hedwig. Beih. 2013, 142, 87-95.

72. Gusev, E.S.; Doan-Nhu, H.; Nguyen-Ngoc, L.; Guseva, E.E.; Phan Tan, L. Silica-Scaled Chrysophytes from Cam Ranh Peninsula (Khanh Hoa Province, Vietnam). Nova Hedwig. Beih. 2019, 148, 63-76. [CrossRef]

73. Gusev, E.S.; Doan-Nhu, H.; Nguyen-Ngoc, L. Silica-Scaled Chrysophytes from Cat Tien National Park (Dong Nai Province, Vietnam). Nova Hedwig. 2017, 105, 347-364. [CrossRef]

74. Gusev, E.S.; Gusakov, V.A.; Guseva, E.E.; Kulikovskiy, M.S.; Tsvetkov, A.I.; Định, C.N. Flora of Silica-Scaled Chrysophytes (Chrysophyceae: Synurales, Paraphysomonadales) of the Mekong Delta. Inland Water Biol. 2020, 13, 349-357. [CrossRef]

75. Doan-Nhu, H.; Thi-Tinh, T.; Gusev, E.; Kulikovskiy, M.; Phan-Tan, L.; Nguyen-Ngoc, L. Taxonomic Composition of Silica-Scaled Chrysophytes in a Tropical Mountain Reservoir. Inland Water Biol. 2021, 14, 490-499. [CrossRef]

76. Gusev, E.; Kezlya, E.; Tran, H.; Kulikovskiy, M. Mallomonas vietnamica sp. nov. (Synurales, Chrysophyceae), a New Species, That Shares Some Features with Fossil Taxa. Cryptogam. Algol. 2021, 42, 39-46. [CrossRef]

77. Gusev, E.; Shkurina, N.; Kulikovskiy, M. Mallomonas loricata sp. nov. (Synurales, Chrysophyceae), a New Tropical Species from Section Plantae. Phytotaxa 2021, 500, 225-233. [CrossRef]

78. Gusev, E.; Kulikovskiy, M. Mallomonas siderea sp. nov. (Synurales, Chrysophyceae), a New Tropical Species from the Section Torquatae. Nova Hedwig. 2021, 113, 291-301. [CrossRef]

79. Gusev, E.S. A New Species of the Genus Mallomonas (Synurophyceae), Mallomonas spinosa sp. nov., from Vietnam. Phytotaxa 2012, $66,1-5$. [CrossRef]

80. Gusev, E.S. A New Species in Genus Mallomonas Perty (Synurales, Chrysophyceae) from Vietnam. Int. J. Algae 2015, 17, 351-362. [CrossRef]

81. Gusev, E.S. A New Species of the Genus Mallomonas (Synurales, Chrysophyceae), Mallomonas fimbriata sp. nov. Phytotaxa 2015, 195, 291-296. [CrossRef]

82. Gusev, E.; Siver, P.A. Mallomonas neoampla sp. nov. from Vietnam, a New Species That Bridges the Gap Between Fossil and Modern Taxa. Nova Hedwig. 2017, 104, 521-528. [CrossRef]

83. Gusev, E.S.; Kulikovskiy, M.S. Two New Species of Genus Mallomonas from Swamp Localities in Vietnam. Phytotaxa 2020, 468 , 121-129. [CrossRef]

84. Gusev, E.S.; Doan-Nhu, H.; Nguyen-Ngoc, L. Mallomonas cattiensis sp. nov. (Synurales, Chrysophyceae), a New Species from Viet Nam. Phytotaxa 2015, 221, 188-192. [CrossRef]

85. Gusev, E.S.; Doan-Nhu, H.; Nguyen-Ngoc, L.; Kapustin, D.A. Two New Species of the Genus Mallomonas from the Cat Tien National Park (Viet Nam): Mallomonas distinguenda and Mallomonas skvortsovii. Phytotaxa 2016, 273, 59-64. [CrossRef]

86. Gusev, E.S.; Siver, P.A.; Shin, W. Mallomonas bronchartiana Compère Revisited: Two New Species Described from Asia. Cryptogam. Algol. 2017, 38, 3-16. [CrossRef] 
87. Gusev, E.S.; Čertnerová, D.; Škaloudová, M.; Škaloud, P. Exploring Cryptic Diversity and Distribution Patterns in the Mallomonas kalinae/rasilis Species Complex with a Description of a New Taxon-Mallomonas furtiva sp. nov. J. Eukaryot. Microbiol. 2018, 65, 38-47. [CrossRef]

88. Gusev, E.; Guseva, E.; Kezlya, E.; Kulikovskiy, M. Mallomonas minuscula sp. nov. (Synurales, Chrysophyceae), a New Member in the Section Torquatae from Vietnam. Fottea 2019, 19, 132-137. [CrossRef]

89. Gusev, E.S.; Kapustin, D.A.; Martynenko, N.A.; Guseva, E.E.; Kulikovskiy, M.S. Mallomonas gusakovii sp. nov. (Chrysophyceae, Synurales), a New Species from Phu Quoc Island, Vietnam. Phytotaxa 2019, 406, 199-205. [CrossRef]

90. Gusev, E.; Kulizin, P.; Guseva, E.; Shkurina, N.; Kulikovskiy, M. Mallomonas lamii sp. nov. (Synurales, Chrysophyceae), a New Species Bearing Large Scales Described from the Tropics. Phytotaxa 2019, 423, 266-272. [CrossRef]

91. Siver, P.A.; Kapustin, D.; Gusev, E. Investigations of Two-Celled Colonies of Synura Formerly Described as Chrysodidymus with Descriptions of Two New Species. Eur. J. Phycol. 2018, 53, 245-255. [CrossRef]

92. Schmidt-Thomé, P.; Nguyen, H.; Pham, L.; Jarva, J.; Nuottimäki, K. Climate Change Adaptation Measures in Vietnam; Springer International Publishing: Cham, Switzerland, 2015; p. 95. [CrossRef]

93. Clescerl, L.S.; Greenberg, A.E.; Eaton, A.D. Standard Methods for The Examination of Water and Wastewater, 20th ed.; American Public Health Association: Washington, DC, USA, 1999; pp. 1-1325.

94. Rowan, K.S. Photosynthetic Pigments of Algae; Cambridge University Press: Cambridge, UK, 1989; pp. 1-334. ISBN 9780521105941.

95. Nürnberg, G.K.; Shaw, M. Productivity of clear and humic lakes: Nutrients, phytoplankton, bacteria. Hydrobiologia 1999, 382, 97-112. [CrossRef]

96. Ngo, V.S.; Le, L.T. Status of reservoir Fisheries in Vietnam. In Reservoir and Culture-Based Fisheries: Biology and Management; De Silva, S.S., Ed.; ACIAR Proceeding: Canberra, Australia, 2001; Volume 98, pp. 29-35.

97. Gusev, E.; Martynenko, N.; Tran, H. Studies on Algae from the Order Synurales (Chrysophyceae) in Northern Vietnam. Diversity 2021, 13, 602. [CrossRef]

98. Guiry, M.D.; Guiry, G.M.; AlgaeBase. World-Wide Electronic Publication, National University of Ireland, Galway. Available online: https:/ / www.algaebase.org (accessed on 5 October 2021).

99. Gusev, E.S.; Kapustin, D.A.; Martynenko, N.A.; Kulikovskiy, M.S. Diversity and Biogeography of Silica-Scaled Chrysophytes (Stramenopiles: Chrysophyceae) from Indonesian Papua. Cryptogam. Algol. 2022, in press.

100. Hansen, P. Silica-scaled Chrysophyceae and Synurophyceae from Madagascar. Arch. Protistenkd. 1996, 147, 145-172. [CrossRef]

101. Franceschini, I.M.; Kristiansen, J.M. New records of scale-bearing chrysophytes for Florianópolis, Santa Catarina Island, Southern Brazil. Algol. Stud. Arch. Hydrobiol. 2004, 111, 63-77. [CrossRef]

102. Wujek, D.E.; Dziedic, R.M. Silica-scaled Chrysophytes from Ecuador. Gayana Bot. 2005, 62, 1-8. [CrossRef]

103. Asmund, B.; Kristiansen, J. The Genus Mallomonas (Chrysophyceae). A Taxonomic Survey Based on The Ultrastructure of Silica Scales and Bristles. Opera Bot. 1986, 85, 1-128.

104. Couté, A.; FranceschinI, I.M. Scale-Bearing Chrysophytes from Acid Water of Florianopolis, Santa Catarina Island, South Brazil. Algol. Stud. 1998, 88, 37-61. [CrossRef]

105. Jo, B.Y.; Shin, W.; Boo, S.M.; Kim, H.S.; Siver, P.A. Studies on Ultrastructure and Three-Gene Phylogeny of the Genus Mallomonas (Synurophyceae). J. Phycol. 2011, 47, 415-425. [CrossRef]

106. Takahashi, E. Studies on Genera Mallomonas and Synura, and Other Plankton in Fresh Water with the Electron Microscope. IX. Mallomonas harrisae sp. nov. (Chrysophyceae). Phycologia 1975, 14, 41-44. [CrossRef]

107. Wei, Y.-X.; Yuan, X.-P. Studies on Silica-Scaled Chrysophytes from Zhejiang, Jiangsu and Jiangxi Provinces, China. Beih. Nova Hedw. 2013, 142, 163-179.

108. Dürschmidt, M. A Taxonomic Study of the Mallomonas mangofera Group (Mallomonadaceae, Chrysophyceae), Including the Description of four New Taxa. Plant Syst. Evol. 1983, 143, 175-196. [CrossRef]

109. Hansen, A.F.; Johansen, J.E.; Skovgard, A. Floristik undersøgelse af skælbærende gulalger i Dyrehaven. Urt 1993, $17,13-18$.

110. Hällfors, G.; Hällfors, S. Records of Chrysophytes with Siliceous Scales (Mallomonadaceae and Paraphysomonadaceae) from Finnish Inland Waters. In Flagellates in Freshwater Ecosystems; Jones, R., Ilmavirta, V., Eds.; Kluwer Academic Publishers: Dordrecht, The Netherlands; Boston, MA, USA; London, UK, 1988; pp. 1-29.

111. Škaloud, P.; Kynčlová, A.; Benada, O.; Kofroňová, O.; Škaloudová, M. Toward a Revision of the Genus Synura, Section Petersenianae (Synurophyceae, Heterokontophyta): Morphological Characterization of Six Pseudo-Cryptic Species. Phycologia 2012, 51, 303-329. [CrossRef]

112. Škaloud, P.; Škaloudová, M.; Procházková, A.; Němcová, Y. Morphological Delineation and Distribution Patterns of Four Newly Described Species within the Synura petersenii Species Complex (Chrysophyceae, Stramenopiles). Eur. J. Phycol. 2014, 49, 213-229. [CrossRef]

113. Jo, B.Y.; Shin, W.; Kim, H.S.; Siver, P.A.; Andersen, R.A. Phylogeny of the Genus Mallomonas (Synurophyceae) and Descriptions of Five New Species on the Basis of Morphological Evidence. Phycologia 2013, 52, 266-278. [CrossRef]

114. Jo, B.Y.; Kim, J.I.; Škaloud, P.; Siver, P.A.; Shin, W. Multigene Phylogeny of Synura (Synurophyceae) and Descriptions of Four New Species Based on Morphological and DNA Evidence. Eur. J. Phycol. 2016, 51, 413-430. [CrossRef]

115. Nemcova, Y.; Rott, E. Diversity of Silica-Scaled Chrysophytes in High-Altitude Alpine Sites (North Tyrol, Austria) Including a Description of Mallomonas pechlaneri sp. nov. Cryptogam. Algol. 2018, 39, 63-83. [CrossRef]

116. Gusev, E.; Kezlya, E. Mallomonas lusca sp. nov-A Rare Species from Southeast Asia. Phytotaxa 2021, 529, 105-112. [CrossRef] 
117. Dürrschmidt, M. New Species of the Genus Mallomonas (Mallomonadaceae, Chrysophyceae) from New Zealand. In Chrysophytes. Aspects and Problems; Kristiansen, J., Andersen, R.A., Eds.; Cambridge University Press: Cambridge, UK, 1986; pp. 87-106.

118. Kim, J.; Hee Park, Y.; Jung Kim, H. Silica-Scaled Chrysophytes (Synurophyceae) from Jeju Island, Korea. Nova Hedwig. 2009, 89, 201-218. [CrossRef]

119. Asmund, B.; Hilliard, D.K. Studies on Chrysophyceae from Some Ponds and Lakes in Alaska. I. Mallomonas species examined with the electron microscope. Hydrobiologia 1961, 17, 237-258. [CrossRef]

120. Dürrschmidt, M. Mallomonas cristata sp. nov. (Chrysophyceae, Synuraceae) from South Chilean Inland Waters. Phycologia 1981, 20, 298-302. [CrossRef]

121. Harris, K.; Bradley, D.E. Some Unusual Chrysophyceae Studied in the Electron Microscope. Microbiology 1958, $18,71-83$. [CrossRef]

122. Siver, P.A. Two New Species of Mallomonas (Synurophyceae) from the Ocala National Forest, Florida, U.S.A. Nord. J. Bot. 2002, 22, 115-121. [CrossRef]

123. Siver, P.A. Lott, A.M. The Scaled Chrysophyte Flora from the Pinelands National Preserve of Southern New Jersey, U.S.A. Nova Hedwig. Beih. 2010, 136, 167-180. [CrossRef]

124. Gusev, E.S.; Guseva, E.E.; Dien, T.D.; Kulikovskiy, M.S. Flora of Silica-Scaled Chrysophytes (Chrysophyceae) of Two Provinces in Southern Viet Nam. Inland Water Biol. 2022, 15. in press.

125. Wujek, D.E.; Kadiri, M.O.; Dziedzic, R.M. Silica-Scaled Chrysophyceae and Synurophyceae from Nigeria. III. Chrysophytes from Rivers of Edo State. Fottea 2010, 10, 93-98. [CrossRef]

126. Kristiansen, J.; Tong, D. Chrysosphaerella annulata n. sp., a New Scale-Bearing Chrysophyte. Nord. J. Bot. 1989, 9, 329-333. [CrossRef]

127. Finlay, B.J. Global Dispersal of Free-Living Microbial Eukaryote Species. Science 2002, 296, 1061-1063. [CrossRef]

128. Finlay, B.J.; Fenchel, T. Cosmopolitan Metapopulations of Free-Living Microbial Eukaryotes. Protist 2004, 155, 237-244. [CrossRef]

129. Finlay, B.J.; Monaghan, E.B.; Maberly, S.C. Hypothesis: The Rate and Scale of Dispersal of Freshwater Diatom Species Is a Function of Their Global Abundance. Protist 2002, 153, 261-273. [CrossRef] [PubMed]

130. Foissner, W. Biogeography and Dispersal of Micro-Organisms: A Review Emphasizing Protists. Acta Protozool. 2006, 45, 111-136.

131. Kristiansen, J.; Lind, J.F. Endemicity in Silica-Scaled Chrysophytes. Nova Hedwig. Beih. 2005, 128, 65-83. 